When the tide gets high: A review of adaptive responses to sea level rise and coastal flooding

Ayşın Dedekorkut-Howes ${ }^{\mathrm{a} *}$, Elnaz Torabi ${ }^{\mathrm{a}}$ and Michael Howes ${ }^{\mathrm{a}}$

${ }^{a}$ School of Environment and Science \& Cities Research Institute, Griffith University, Gold Coast, Australia

*Email: a.dedekorkut@griffith.edu.au, School of Environment and Science, G31, 3.05, Gold Coast Campus, Griffith University, Queensland 4222, Australia 


\title{
When the tide gets high: A review of adaptive responses to sea level rise and coastal flooding
}

\author{
Climate change poses significant challenges to coastal cities. Local governments around \\ the world are using various strategies to address sea level rise and coastal flooding. \\ Most of these responses are reactive, developed in an ad hoc manner following a \\ specific event, but there is an increasing recognition of the need for more \\ comprehensive and proactive approaches. Research into the topic reflects practice, with \\ numerous studies of particular locations or strategies providing information in a \\ piecemeal manner lacking in comprehensive evaluations. This paper addresses this gap \\ through a systematic literature review that identifies coastal flooding and sea level rise \\ adaptation practices and evaluates their comparative advantages and disadvantages. The \\ findings identify a major knowledge gap in comparative costs and benefits of \\ alternative adaptation strategies and indicate that coastal climate adaptation needs to be \\ tailored to local characteristics and use a combination of different structural and non- \\ structural measures to be effective.
}

Keywords: climate adaptation; strategies and measures; planned retreat; ecosystembased responses; integrated approaches

\section{Introduction}

Almost half of the world's population (44\%) lives in coastal regions within 150 kilometres of the sea (UN Atlas of the Oceans n.d.). Coupled with rapid population growth and increasing development pressures, the impacts of climate change pose growing social, economic and environmental risks to these settlements. A recent special report of the Intergovernmental Panel on Climate Change (IPCC 2018) highlights the serious risks of sea level rise (SLR) and coastal flooding, which will be particularly felt in low-lying coastal areas. These areas are often home to the most vulnerable groups of the society who are living in substandard housing and lack the resources and capacity necessary to cope with the impacts of disasters (McGranahan et al. 2007; UN-Habitat 2013). Despite the urgency of the matter, actions to date have been limited and varied across localities (Hoppe et al. 2014; van den Berg and 
Coenen 2012).

Cities use diverse strategies to reduce their vulnerability to sea level rise and coastal flooding. Various typologies classify these adaptive responses based on the strategies used, the types of measures adopted, the level of deliberation, and the adaptation location. The most common strategies are encapsulated in the protect, accommodate, and retreat (PAR) model first proposed by the Coastal Zone Management Subgroup of the Intergovernmental Panel on Climate Change (Dronkers and Mulder 1990). The protection strategy is based on the defence of vulnerable areas where population, built assets, economic activity, and natural resources are located by decreasing the impacts of a negative event. Accommodation involves the continued use of vulnerable areas while enhancing the capacity of the population and the natural and built environment to cope with impacts, while retreat requires the "abandonment of land and structures in vulnerable areas and resettlements of inhabitants” (Dronkers and Mulder 1990: 146). A few studies identify the additional category of 'attack’ (Lee 2014; Nicholls 2011: 152) which involves ‘advancing the line’ of resilient development seaward. The PAR model and its variants are still widely cited across the literature albeit employing different terms. Various combinations of these strategies are also found in practice (Nicholls 2011).

The distinctions between these strategies are not so clear, however, and there is significant overlap in their conceptualisations. What one researcher considers accommodation, another may view as protection. As a result, land reclamation shows up under all four major strategies (see Figure 1).

[Figure 1 near here] 
Another way to categorise adaptive responses depends on the types of measures used (see Cai et al. 2009; Cisneros Linares 2013; Douglas et al. 2012; Munaretto et al. 2012). Structural measures include technological and engineering approaches to manage the impacts of coastal flooding and SLR, while non-structural measures include legal, institutional, and organisational measures (such as legislation, policy, planning and management instruments, public awareness raising, etc.) that are essential for effective responses (Dawson et al. 2011; Idllalène and Van Cauwenbergh 2016; Lee 2014). Hard measures consist of the use of physical (engineering) structures, while soft measures focus more on techniques utilising natural ecosystem-based approaches (Cisneros Linares 2013; Douglas et al. 2012). Structural measures include both hard protection measures such as seawalls, dikes, dams, etc. as well as soft measures which typically include beach nourishment and protection or construction of saltmarshes and wetlands, etc. (Lee 2014). These terms are not used consistently across the literature either, as some researchers consider soft measures as a synonym for non-structural measures such as land use planning, insurance, early warning systems, evacuation planning, or moving belongings to higher ground (e.g. Hallegatte 2009; Jamero 2017). To avoid this confusion in terminology we will use the term 'ecosystem-based' for natural soft measures and 'non-structural' for institutional measures.

Adaptation can be planned (measures taken by deliberate and proactive forward planning) or unplanned (autonomous or reactive actions that evolve as circumstances change) (Cooper and Lemckert 2012; Harwitasari and Van Ast 2011; Lonsdale et al. 2008; Tol et al. 2008). Measures can take place in situ or ex situ. In situ adaptation usually includes the measures undertaken "in place of normal living or origin”, while ex situ adaptation includes retreat or relocation elsewhere (Jamero et al. 2017; Saroar and Routray 2010).

Added to this multiplicity of options, confusion of terminology, and inconsistent and overlapping categorizations, research on this topic so far has been piecemeal, focusing on: 
(1) solutions to a single particular problem such as coastal erosion (Cai et al. 2009), storm surge (Challender 2016; Harman et al 2013), or flooding (Fabiyi and Yesuf 2013;

Fasona 2003; Harwitasari and Van Ast 2011; Munaretto et al. 2012);

(2) case studies examining options for particular locations ranging from the national scale such as Australia (Gurran et al. 2013), Bahrain (Al-Jeneid et al. 2008), Croatia (Baric et al. 2008), Gambia (Jallow et al. 1996), and the Netherlands (Kwadijk et al. 2010) to regional scale such as the south coast of England (Bray et al. 1997), to city scale such as Cavite City, Philippines (Sales Jr 2009), Gold Coast, Australia (Cooper \& Lemckert 2012), and Mokpo, Korea (Lee 2014);

(3) vulnerability of specific assets or activities such as nuclear energy infrastructure (Choate III 2011), water resources (Hay and Mimura 2005), or coastal tourism (Scott et al. 2012); or

(4) only particular types of strategies such as planned retreat (Abel et al. 2011; Alexander et al. 2012), rolling easements (McLaughlin 2011), ecosystem-based approaches (Alverson et al. 2012; Cisneros Linares 2013), and beach nourishment (Cooke et al. 2012).

In the absence of a comprehensive review and evaluation covering all impacts and strategies, it is unclear which options provide better solutions under which conditions. In order to address this gap, this paper provides a systematic examination of the literature to identify adaptive strategies and measures, evaluate their relative advantages and disadvantages, and discuss their implications across different contexts. After outlining the details of our methods, we provide a brief overview of the literature on the major types of strategies (PAR model) but structure our presentation of the actual measures independently of these categories in order to eliminate overlap. We then offer a detailed discussion of each one and conclude with a summary of the key points and areas of future research. 


\section{Methods}

This study employs a systematic quantitative review of the literature. This involves the identification and synthesis of all available evidence to generate a robust answer to research questions that is supported by empirical evidence (Mallet et al. 2012). This method provides a holistic assessment of the literature based on the key research themes identified by the researchers (Pickering and Byrne 2014) and has been employed on a range of topics from parks provision (Boulton et al. 2018) to sustainability (Howes et al. 2017). Systematic literature reviews can reduce the 'researcher bias' resulting from the tendency of researchers to limit traditional reviews only to the literature within their own subject areas and networks by following a set research protocol (Mallet et al. 2012). The focus of the systematic review in this paper is on identifying the existing adaptation responses to SLR and coastal flooding, their advantages/disadvantages, and any potential barriers/enablers.

The review follows the protocols of the Preferred Reporting Items for Systematic Reviews and Meta-Analyses (PRISMA) statement (Moher et al. 2009). Search strings used in Google Scholar and Scopus databases combined two sets of concepts: 1) practice/s, strategy/ies, measure/s, action/s, approach/es; and, 2) coastal flooding, storm surge, sea level rise. We conducted two sets of searches in each database (by title only and full text) and limited our review to first 100 results by relevance in full text search. This process returned a total of 1736 records (see Figure 2 for the PRISMA diagram). Initial screening process removed the duplicates and limited the database to scholarly peer-reviewed journal articles. The remaining 382 records were assessed for eligibility and items that did not meet the inclusion criteria (e.g. not relevant to human-organised responses, in other languages, etc.) were excluded resulting in 119 relevant articles to be included in the quantitative review. These are marked by an asterisk in the list of references. 
[Figure 2 near here]

\section{Sea level rise and coastal flooding response strategies}

From the PAR model, the literature focuses more on protection and accommodation strategies in comparison to retreat (Table 1). There is a strong emphasis on structural protection measures (both hard and ecosystem-based such as building seawalls, beach nourishment, embankments, etc.) and hard accommodation measures such as raising the buildings and key infrastructure. Financial factors may explain this, since many coastal areas have already been developed, and retreat in many cases is not a viable economic option unless the risk is too high. Ecosystem-based soft measures in accommodating the risks of coastal flooding and SLR have largely been neglected.

While quite rare in the literature, 'attack' is mentioned as a separate strategy from general protection in two articles. This includes measures undertaken for seaward advancement of the coastline via the construction of piers, decks, and land reclamation. The focus of these cases is on 'advancing the line' as opposed to holding it (Nicholls 2011: 152). Protection is the most frequently discussed strategy in the literature indicating the tendency of defending investments rather than undertaking radical changes. It is effective in responding to SLR and coastal flooding because it requires minimum changes to the existing built environment and land use (Harman et al. 2013) as well as its potential for stabilising/enhancing the coastal environment. Protection strategies include structural and non-structural measures and structural protection may involve hard, soft, or hybrid measures. As the second most popular strategy, accommodation is a preferred choice for adaptation by the community, politicians, and local experts (Douglas et al. 2012; Harwitasari and Van Ast 2011; Jamero et al. 2017; Lewis 1990; Marengo et al. 2017; Sahin et al. 2013; Saroar and Routray 2010). One of the benefits of accommodation strategies is that they can easily be 
combined and integrated with other strategies, such as protection and retreat (Bray et al. 1997). An important barrier to accommodation measures (such as raising elevation of buildings or infrastructure upgrades) is the interdependence of different infrastructure systems that require a comprehensive approach and the cost of upgrades that pose a particular challenge for renter-occupied properties (de Almeida and Mostafavi 2016). Approximately half of the articles (49.6\%) discussed retreat (including planned/managed retreat or realignment) as an important adaptation option for many low-lying coastal areas that can no longer afford to defend against SLR and coastal flooding. What is referred to as retreat, however, is considerably diverse across the literature with varying terminology that covers five major types of strategies: migration/abandonment, planned/managed retreat/realignment to higher land behind the coasts using bigger setbacks, temporary retreat and relocation, engineered retreat, and vertical retreat.

[Table 1 near here]

\section{Response measures to sea level rise and coastal flooding}

The overall adaptation measures discussed in the literature can broadly be grouped into four main categories for practical purposes: structural (engineering and ecosystem-based), nonstructural (institutional), retreat, and integrated measures. Most of the measures used for protection and accommodation strategies are structural but require to be supported by nonstructural measures to be effective and retreat involves various non-structural measures. 


\subsection{Structural adaptation}

\subsubsection{Hard structural measures}

Hard structural measures include engineering to protect existing developments and infrastructure and/or accommodate the impacts of sea level rise and coastal flooding in an existing or new development. Table 2 presents the key advantages and disadvantages of these measures which are then discussed in detail.

[Table 2 near here]

The most common hard structural measure is a seawall: "a structure, often concrete or stone, built along a portion of a coast to prevent erosion and other damage by wave action. Often it retains earth against its shoreward face” (US Army Corps of Engineers [USACE] 2003). In comparison to other protection measures, the aesthetic impact of seawalls is a key disadvantage that makes them unsuitable for some coastal resorts (Scott et al. 2012; Walsh et al. 2004). Determining who is responsible for their construction and maintenance is an important barrier to effective seawall implementation as the community usually expects the government to provide the necessary funds (Barron et al. 2012; Harman et al. 2013; Harwitasari and Van Ast 2011).

The second most frequently mentioned hard structural measure is raising the elevation of existing infrastructure, buildings, assets, structures, and roads to accommodate coastal flooding and SLR. This is an expensive option requiring considerable government support and is viable only for those with sufficient funds (Birkmann et al. 2010; Frazier et al. 2010). Barriers include the unsuitability of some current structures and housing types for raising (e.g. basement apartments), the unattractive building forms that may result, and the difficulty and length of the process (Douglas et al. 2012). It may also not be feasible in the long-term as 
elevating critical infrastructure, for example, will not reduce the level of vulnerability of population in high risk areas (de Almeida and Mostafavi 2016). The government usually has the responsibility to inform the public and provide financial incentives for elevating new and existing development at high risk areas (de Almeida and Mostafavi 2016; Frazier et al. 2010). Increasing density in some areas is an important strategic incentive for sharing the cost of implementing such measures (Barron et al. 2012).

Dikes and dike rings are examples of an "earth structure along sea or river in order to protect low lands from flooding by high water” (USACE 2003: A 23). Dikes have significant negative impacts on the environment by blocking the introduction of sediments and water into the coastal zone which can result in loss of wetlands (Day Jr and Templet 1989; VanKoningsveld et al. 2008; Vellinga and Leatherman 1989). When used with active pumping and drainage, dikes can be very effective in preventing coastal flooding (Kwadijk et al. 2010; Lee 2014; Nicholls 1995), but they can lead to an increased risk of land subsidence (Nicholls 1995; Vellinga and Leatherman 1989). Existing dikes can be retrofitted in response to future SLR; however, there may be difficulties in retrofitting or relocating houses that are close to dikes or on them (Tol et al. 2008). More sustainable protection requires further improvement of legislation, dike design standards (Pilarczyk and Nuoi 2005), and the establishment of responsible authorities (e.g. regional water bodies) with relevant policies and management guidelines, as well as the formation of special boards to carry out dike maintenance (VanKoningsveld et al. 2008).

The flood proofing of houses and infrastructure through improved construction techniques, materials, restoration, and use of waterproofing measures is another important structural option. Overall, it is more cost-effective than protection or retreat and therefore popular amongst the community and politicians (Jamero et al. 2017; Sahin et al. 2013). The upgrade of existing drainage and stormwater infrastructure can be achieved through water 
conservation and management including runoff storage, improved water reticulation and use of water retention ponds (Birkmann et al. 2010; Dawson et al. 2011; Hay and Mimura 2005; Lewis 1990); enhancing the capacity of stormwater pumping (de Almeida and Mostafavi 2016; Harwitasari and Van Ast 2011; Lacerda et al. 2014; Wong 1992); adjustments to sewage treatment plants (Birkmann et al. 2010; Munaretto et al. 2012); the use of submersible pumps (Rosenzweig et al. 2011); and, the effective use of culverts and gutters (Fabiyi and Yesuf 2016). The artificial recharge of aquifers by injecting stormwater is one of the best adaptive practices as it accommodates SLR and creates a barrier to saltwater intrusion as well as controlling land subsidence in some cases by maintaining groundwater levels (de Almeida and Mostafavi 2016).

Land reclamation and the creation of new land along the coast is an effective adaptation strategy for some locations. This can be in the form of wetland/swampland reclamation by planting new species (Munji et al. 2013); the creation of new land such as artificial headlands (Alexander et al. 2012); raising islands (Vellinga and Leatherman 1989); ridging and terracing farmlands in coastal areas (Musa et al. 2016); and, the creation of multilayered terraces along the coast (Lee 2014). Despite the benefits in adapting to SLR and coastal flooding, land reclamation requires resources as well as maintenance and can exacerbate vulnerability to SLR (see Table 2).

A groyne (American, groin) is a "narrow, roughly shore-normal structure built to reduce longshore currents, and/or to trap and retain littoral material. Most groins are of timber or rock and extend from a seawall, or the backshore, well onto the foreshore and rarely even further offshore” (USACE 2003: A34). While easier to build compared to other measures, groynes can alter the beach line and trigger erosion (Jallow et al. 1996; Rosenzweig et al. 2011). Like seawalls, levees are a type of "large dike or artificial embankment, often having an access road along the top, which is designed as part of a system to protect land from 
floods” (USACE 2003: A44). Levees are not viewed as a long-term solution due to their encouragement of an out of proportion sense of safety, also known as the "levee effect" (Lawrence et al. 2015; van Wesenbeeck et al. 2014).

At smaller scales floodgates are crucial for controlling saltwater intrusion into groundwater and agriculture (de Almeida and Mostafavi 2016; Sales 2009). At larger scales, storm surge barriers are effective with a one-off cost and least disruption to city life and can provide additional benefits (see Table 2). However, they can create negative social impacts as the protected areas will be viewed as receiving favourable treatment from the government compared to other parts of a city (Lonsdale et al. 2008). Considering the uncertainties around SLR impacts and the slow onset of hazard, many governments are concerned that they will be perceived to be wasting tax payers' money, if the risks do not materialise (Lonsdale et al. 2008)

Other hard structural measures mentioned in the literature include breakwaters, embankments, revetments, jetties, sandbags, gabion baskets, floating houses, and piers and ports. There is scant discussion on the specific benefits or implications of these measures (including barriers and enablers); however, disadvantages such as negative environmental impacts and high cost were highlighted for some of them. Only one article in the review considers the implications of shared and individual floating houses including benefits such as cost sharing and community building through great neighbourhood relationships but warns about the complexity of decision making in urban planning, the consideration of public buildings (e.g. child care, schools, playgrounds), and the issue of public space on a floating house/community (Trang 2016). Rubbles, artificial reefs, and impoundments were only mentioned in passing.

Overall, more disadvantages of hard structures (especially protection measures) are discussed in the literature compared to their advantages (see Table 2). The use of hard 
structural measures can be a very effective strategy for protection of high-value developed areas (Nicholls 2011; Tobey et al. 2010). One of the main benefits of hard protection is that actions do not require major institutional changes such as variations to existing land use (Harman et al. 2013; Walsh et al. 2004). Other benefits include satisfying the residents’ wish to maintain their current lifestyle by not relocating (Sahin et al. 2013); stabilising cliffs and retaining shoreland (Good 1994); and the potential to produce electricity (Pilarczyk and Nuoi 2005). However, there are high costs involved in the construction and upgrade of infrastructure and buildings. For instance, the cost of retrofitting existing hard protection structures is greater than designing them from the start with enough flexibility to allow for the impacts of SLR (Tobey et al. 2010; Tol et al. 2008) and residents usually do not want to pay more tax for protection (Taylor et al. 2013). Equally important is the negative impact of hard protection measures on the environment and particularly the degradation of the natural environment, decreasing its resilience, and increasing the risks of erosion (Good 1994; Musa et al. 2016; Solecki 2012). Hard protection is also criticised for propelling development in high risk areas and giving a false sense of security due to the underestimation of risks and over-confidence in protective measures (Birkmann et al. 2010; Bray et al. 1997; Dawson et al. 2011; Devoy 1992; Leatherman and Beller-Simms 1997). Hard protection measures are only as effective as their weakest part, usually require a long construction time (Hallegatte 2009; Lonsdale et al. 2008), deteriorate over time (Harman et al. 2013), need constant assessment and maintenance (Solecki et al. 2011; Sterr 2008), are aesthetically unpleasant, and limit physical and management flexibility (Bray et al. 1997; McLaughlin 2011).

The most common enabler for large scale structural protection projects is the availability of funding from governments (Douglas et al. 2012; Fabiyi and Yesuf 2016; Harman et al. 2013). However, many institutional barriers need to be overcome first, including the political and economic debate on the level of safety required (Pilarczyk and 
Nuoi 2005), the lack of information about the negative impacts of hard structural measures (Birkmann et al. 2010), a lack of institutional capacity for planning, analysis, assessment, etc. (Birkmann et al. 2010; Donner and Webber 2014), and the lack of a uniform response path across community and state borders (Sterr 2008).

\subsubsection{Ecosystem-based structural measures}

Ecosystem or nature-based adaptation includes favouring ecosystems and the use of mangroves, coral reefs, estuaries, seagrass beds, dune communities, and other systems on or near shorelines (Table 3). They provide benefits in terms of protection from storms, mitigating floods, controlling erosion, providing water storage, and retaining nutrients and sediments (Tobey et al. 2010).

[Table 3 near here]

Beach nourishment (mostly artificial by using external fill material) as a sediment management strategy is the most popular ecosystem-based structural measure discussed in the literature for protection against SLR and coastal flooding; however, it can be expensive and have negative impacts on the environment. To be successful, beach nourishment projects need to be supplemented with prior environmental impact assessments to better connect management, monitoring, and reporting practices (Cisneros Linares 2013; Cooke et al. 2012). The main barrier to their success is the availability of sediment and sand (Cooper and Lemckert 2012; de la Vega-Leinert and Nicholls 2008; Leatherman and Beller-Simms 1997; Walsh et al. 2004). It is also necessary to prohibit unreasonable sand mining to allow for sustainable protection of the coast against SLR and coastal flooding (Abel et al. 2011; Cai et al. 2009; Musa et al. 2016). The availability of funding from higher levels of government, 
particularly at the national level, is an important enabler of beach nourishment projects (Harman et al. 2013).

The second most common ecosystem-based structural measure is the preservation of vegetation including wetlands, mangroves, and saltmarshes. Wetlands are important for ensuring coastal sustainability (Ayyub and Kearney 2011). Wetland loss may be prevented by maintaining the sediment supply to coastal wetlands by allowing coastal erosion to continue so they can grow in place. Complementary strategies such as retreat and accommodation to create space for wetland migration may also be beneficial (Nicholls et al. 1999). Mangrove preservation is a no regrets strategy (Alverson 2012) that can contribute to soil richness (de Almeida and Mostafavi 2016). Some priority areas of action for the protection of mangroves include the establishment of a buffer zone, reforestation of mudflats along the beach, reviving traditional agriculture systems around mangroves, and launching national campaigns to raise public awareness (Al-Jeneid et al. 2008). While no specific advantages of saltmarshes are mentioned, one article notes the challenges of assessing the degree of protection provided by these types of ecosystem-based measures and points to the differences in marsh canopy heights, structure, biomass, and extent of coverage that can significantly influence the results (Ayyub and Kearney 2011).

Dune restoration is a cost-effective measure that can be undertaken by ceasing/limiting the activities that adversely affect coastal sediments, planting trees, or fencing off sensitive areas. Other cost-effective measures that also provide environmental benefits include reforestation and afforestation, coral reefs, natural barrier walls, and natural drainage. Coral reefs, for instance, can reduce wave energy and provide protection against storm surges. Al-Jeneid et al. (2008) highlight the importance of rehabilitation of corals, the enforcement of specific legislation for marine resources, coral reef monitoring, and the 
creation of a network of actors for regional collaboration as priority actions for effective use of coral reefs in adapting to climate change.

The literature details more advantages of ecosystem-based structural measures than hard structural measures. Their positive impacts on the environment include capacity to enhance natural coastal environment, increase resilience, control erosion, and a greater costeffectiveness compared to hard protection measures (Abel et al. 2011; Alexander et al. 2012; Cisneros Linares 2013; Lee 2014; Tobey et al. 2010; van Wesenbeeck et al. 2014). They are also important for enhancing environmental amenity and the recreational value of the coastal zone (Bray et al. 1997; Cisneros Linares 2013; Douglas et al. 2012). They provide natural scenery and are aesthetically more pleasing compared to hard protection structures (Abel et al. 2011; Cisneros Linares 2013). They also provide many goods and services for humans including water storage and groundwater recharge capacity (Tobey et al. 2010) as well as more potential for tourism activities (Cisneros Linares 2013). However, ecosystem-based measures need intensive maintenance and require subsequent extensive monitoring and research (Bray et al. 1997). Furthermore, their implementation needs space, which is a scarce coastal resource (Pethick 2002) and they are perceived as less reassuring compared to hard structural measures by many decision makers and the community (de la Vega-Leinert and Nicholl 2008). The difficulty in quantifying the value of these benefits is a significant barrier, which underscores the need to review coastal protection policies as new environmental economic techniques become available (Bray et al. 1997). The re-evaluation of coastal protection policy needs to consider the environmental impacts of hard structures and allow them only after an evaluation of alternatives with less environmental harm (Storbjörk and Hedrén 2011).

\subsubsection{Hybrid structural measures}

While less common than hard and ecosystem-based protections, hybrid approaches to coastal 
risk reduction combine natural infrastructure (healthy ecosystems) with built infrastructure such as seawalls (Sutton-Grier et al. 2015). The literature suggests that there are more advantages of hybrid approaches than disadvantages (Table 4). Examples of these measures include the enhancement of ecologically functional barrier islands in addition to reinforcement of existing dikes and seawalls (Barron et al. 2012) or the innovative sand management and groyne systems that can be complemented by seawalls in the long-term (Jallow et al. 1996). Other types of hybrid measures include soft engineering techniques such as dune restoration using geotextile materials (Small 2016), beach dewatering and drainage, submerged geosynthetic container systems (Cisneros Linares 2013; Harman et al. 2013; Scott et al. 2012; Small et al. 2016), and the use of biotechnical structures such as artificial seagrass and artificial mangrove roots. Dune restoration with geotextiles is a cost-effective solution in the short term that can provide decision makers with the opportunity to assess actual impacts of SLR for the longer term (Small 2016). Filled geosynthetic containers are used as artificial reefs in Australia, New Zealand, USA, and UK and provide multiple benefits. The Narrowneck Reef on the Gold Coast, Australia, for instance, provides beach protection and improved surf conditions in the area (Harman et al. 2013). Biotechnical structures mimic the natural characteristics of plants such as mangroves in breaking waves and can protect the shoreline against the impacts of storm surges (Cisneros Linares 2013). Although not explicitly referring to combined/hybrid strategies, Donner and Webber (2014) suggest that best practice for construction of seawalls should include shallow slopes with sufficient beach and vegetation, protective mesh to protect fill, adequate drainage and height, and consideration of capturing rather than losing sediments.

[Table 4 near here] 
Another hybrid measure example is the living shoreline strategy, which utilises a variety of structural and organic materials. As a no regrets strategy (Tobey et al. 2010) in contrast to seawalls the living shoreline provides habitats that grow (McLaughlin 2011) in an economically efficient way (Harman et al. 2013). However, this strategy is not suited for areas with high wave energy and needs more assessment and monitoring to be established internationally (Harman et al. 2013). Encouraging alternatives to structural hard protection including a living shoreline approach can raise concerns for governments in terms of community opposition and the possibility of the compulsory acquisition of property that requires compensation (McLaughlin 2011).

\subsection{Non-structural adaptation}

Non-structural measures are those that do not involve any physical construction and instead use knowledge, practice, or agreement to reduce risks and impacts (UNISDR 2009). They can be legal, institutional, and organisational measures such as legislation, policy, regulation, etc. (Munaretto et al. 2012). Most of the articles in our review promoted non-structural adaptation strategies to address the impacts of SLR and coastal flooding (see Table 1). This is not surprising, as most structural measures have non-structural components or need to be supported by non-structural measures to be effective.

Of all non-structural measures, planning policy and regulations is mentioned most frequently (see Table 5). Incorporating climate change and SLR into the planning process can involve the use of policy tools such as the requirement for freeboards (height of the watertight portion of a structure), setbacks, and changes to land use zoning regulations (see Gurran et al. 2013; Hurlimann et al. 2014; Idllalène 2013; Yusuf et al. 2016). Planning policy and regulations are particularly critical in accommodating the impacts of SLR and coastal flooding. The main measures in this context are amendments to building codes and zoning, requirement of setbacks including natural buffers (Devoy 2008; Donner and Webber 2014; 
Harman et al. 2013; Leatherman and Beller-Simms 1997; Primo 1997; Tobey et al. 2010); and the requirement for freeboards above designated flood and storm surge levels (Al-Jeneid et al. 2008; Harman et al. 2013; Susskind 2010; Symes et al. 2009; Tol et al. 2008; Walsh et al. 2004). The main pathway for ensuring the appropriate integration of SLR and climate change impacts into policies at the local level is through mandatory requirements from higher level policies (Harman et al. 2013; Symes et al. 2009). For instance, the lack of a mandatory freeboard requirement by state governments led to inconsistent responses across local governments in Australia (Harman et al. 2013). Providing incentives such as grants and tax rebates to homeowners and small businesses in risky areas for encouraging adaptation measures is crucial for implementation of accommodation strategies (e.g. raising houses) (Munaretto et al. 2012; Susskind 2010). This is especially important as communities are resistant to relocating (Harwitasari and Van Ast 2011).

[Table 5 near here]

Community capacity building is the second most frequent non-structural measure noted in the literature. Enhancing the capacity of the community entails processes that support social learning, raise awareness, improve community outreach and engagement, and build financial capacity via tools such as cost sharing/insurance (see Marshall and Allan Owens 2014). As accommodation of the impacts of SLR and coastal flooding requires changes to the existing lifestyle of communities (e.g. the need for raising houses, etc.), they need to be supported by programs to share information and raise public awareness about both impacts and adaptation options (see Devoy 1992; Godschalk et al. 2000; Nicholls 2011). Awareness raising measures include informing land owners and buyers about the risks of coastal flooding and SLR (Susskind 2010; Wolf 2013). The standard methods of public engagement include information dissemination (e.g. hearings and public notice) and information collection (e.g. 
surveys and focus groups); however, more active involvement by key stakeholder groups and the community is required to justify the investment in adaptation planning (Susskind 2010). Harman et al. (2013) underscore some existing barriers to public risk disclosure including strong objections from property owners to the inclusion of risks in land titles (due to the implications for property values) and associated equity concerns that might arise.

Financial tools can encourage the uptake of adaptation measures, discourage development in high risk areas, or support planned retreat. This includes compensation for land owners (such as tax breaks) for flood management, incentives for relocations and steering development away from the high risk areas, assistance to flood victims (such as loans and grants), the provision of temporary accommodation, subsidies, and tax and/or reduced local government rate incentives for the implementation of best management practices. Insurance can help communities in coping with impacts. The utilisation of comprehensive home insurance, for instance, is important in enhancing the adaptive capacity of the community. Yet, the decreasing affordability of insurance with increasing risks of SLR can pose an important barrier for adaptation (Solecki 2012). A more active engagement with the insurance industry in planning processes is therefore important (de la Vega-Leinert and Nicholls 2008). The role of indigenous knowledge in adaptation was specifically mentioned in four articles (Ehler et al. 1997; Fabiyi and Oloukoi 2013; Haque et al. 2016; Solecki et al. 2011).

Disaster risk reduction measures discussed in the reviewed literature include hazard warning and monitoring, improved information and forecasting, hazard risk assessment and vulnerability modelling, more research, and the use of technology (such as remote sensing) in preparing for and coping with impacts. These include measures that help managers and communities to prepare for extreme events such as improved flood forecasting and early warning systems (see Khalil 1992; Solecki 2012). Some examples apply geospatial tools to 
multi-criteria approaches (Harik et al. 2017; Islam et al. 2016; Maanan et al. 2018) or fuzzy logic based spatial techniques (Mullick et al. 2019) for coastal vulnerability assessments, examine the spatiotemporal evolution of ecological risk patterns (Liu et al. 2018), or propose applying social-ecological resilience concepts to geomorphic systems (Chaffin and Scown 2018) for better informed decision making. While the lower cost of these measures is noted (Khalil 1992), their effectiveness is unclear. Other risk reduction measures include preparation of emergency plans including temporary evacuation plans for the communities that continue to live in high-risk areas (Douglas et al. 2012; Harman et al. 2013; Jamero et al. 2017; Solecki 2012).

Hazard and vulnerability mapping for identification of areas exposed to sea level rise under different scenarios is an important institutional tool to base accommodation strategies (de Almeida and Mostafavi 2016; Godschalk et al. 2000; Nicholls 2011). Geospatial techniques such as multi-criteria integrated risk mapping approach can produce detailed risk assessments that can be used by policymakers and administrators (Hoque et al. 2018). Spatial analysis through geographic information systems can help selection of suitable resources and safe locations for emergency shelters in a multi-hazard environment (Chen et al. 2018). Mapping of potential shelters in relation to hazards can assist planners and emergency managers in developing disaster management and evacuation plans (Masuya et al. 2015). The availability of hydraulic data to ensure appropriate drainage and engineering reports to certify that structures can withstand impacts of SLR and coastal flooding are also important in making sure that the built environment has the capacity to accommodate impacts (Symes et al. 2009).

Coastal planning and management policies can regulate the natural environment to accommodate the impacts of SLR and coastal flooding through the maintenance and protection of important ecosystems, the regulated use of ecologically risky zones, and the 
designation of retention and infiltration areas (Bray et al. 1997; Devoy 1992; Harty 2004; Jianjun and Francisco 2013; Lonsdale et al. 2008; Sales 2009; Storbjörk and Hedrén 2011; Storch and Downes 2011; VanKoningsveld et al. 2008). The concept of "working with nature” shifts the paradigm from seeing water as "the enemy” to acknowledging it as "an ally" (VanKoningsveld et al. 2008: 376), which is an important institutional consideration in adaptation (Lonsdale et al. 2008; Storbjörk and Hedrén 2011). Lonsdale et al. (2008) suggest that climate change will require new institutions that embed flexibility in decision making and require a shift from managing nature to working with nature. Coastal planning and management policies also include measures regarding protection against the coastal impacts of climate change. Good (1994) points to some constraints for effective shore protection through his policy evaluation in Oregon, USA, including the uncoordinated planning for beaches and coastal areas, the proliferation of protection response due to local responses that are aimed mainly at managing growth, and a very reactive shore protection permit process prepared and submitted by property owners or their consultants. Similarly, Platt (1985) suggests that local political jurisdictions in coastal areas are geographically diverse and lack the necessary resources to analyse development plans, which translates into high fragmentation of local governance of coastal barriers across different states. Day Jr and Templet (1989) suggest that coastal management for protection needs to appropriately transform ecological values into economic values. They suggest land units based on natural landscape (rather than existing parcel allocations) to be more suitable for coastal management. Tobey et al. (2010) highlight the importance of nature-based protection strategies as part of a broader integrated coastal zone management approach, including the protection of corals and ensuring the connectivity between habitats. They argue that coastal protection schemes need to cover large areas to be effective. 
Another non-structural measure of adaptation to coastal flooding and SLR is adaptive management and governance. This includes institutional capacity building and integration between different actors at different levels of governance, stakeholder engagement in decision making processes, and processes that support the co-generation of knowledge. Effective stakeholder engagement and collective decision making at different levels are key underpinnings of this approach (Lawrence et al. 2015; Munaretto and Huitema 2012; Susskind 2010; Yusuf et al. 2016; Camill et al. 2012). More flexible and inclusive governance structures and new methodological tools that go beyond cost-benefit analysis are required (Birkmann et al. 2010). Policentricity, participation, experimentation, and undertaking a bioregional approach are crucial for creating an adaptive management approach (Munaretto and Huitema 2012). Inconsistency between different institutional, cultural, and political norms that require greater intervention are important constraints undermining institutional capacity (Harman et al. 2013).

Non-structural measures such as the inclusion of SLR considerations in policy, raising community awareness, etc., are generally viewed as cost-effective tools of adaptation (DeLorme et al. 2018; Jallow et al. 1996). However, analysing the actual costs and benefits of these measures has been very limited in the literature, due to the complexity of analysing all the elements and interactions of the socio-economic systems (Dawson et al. 2011). An important barrier to implementation of non-structural measures is the need for major changes to, and reorganisation of, existing institutional settings (Dawson et al. 2011; Munaretto et al. 2012). Although some non-structural measures can influence longer term trends of development in the floodplain, generally the benefits of such measures are greater if they are implemented early in the process of planning (Dawson et al. 2011). Moreover, there is usually a higher level of detail regarding the implementation of structural measures compared to nonstructural measures (Birkmann et al. 2010). 


\subsection{Retreat strategies}

\subsubsection{Horizontal planned retreat to higher land}

The managed/planned abandonment of low-lying high risk areas is related to the use of wide setback restrictions that provide a buffer zone between development and the coast. Due to the negative connotations of the term, which evokes strong political and public opposition, retreat has occasionally been reframed as 'managed realignment' behind beaches, dunes, wetlands, and saltmarshes (Bray et al. 1997; Harman et al. 2013; Pethick 2002). Many researchers consider managed realignment as a retreat option that enhances coastal habitats and biodiversity, allowing for large expansion of saltmarshes by forbidding hard defence structures (Boori and Amaro 2011; Boori et al. 2012; Dawson et al. 2011; Harman et al. 2013; Lonsdale et al. 2008; Paskoff 2004; Pethick 2002; Tol et al. 2008; van Slobbe et al. 2013); however, the meaning of the term is neither clear nor unanimous. Managed realignment strategies in the UK, for example, consider coastal restoration as part of improving the stability of the coastline, effectively replacing artificial hard structures with ecosystem-based protection, whereas in the USA it is seen as a conservation policy to increase wetland habitat (Pethick 2002). When realignment includes measures to achieve elevation and sediment stability it can provide environmental benefits, yet the cost of such measures can impact on the feasibility of managed realignment (French 2008). It can also include relocation/realignment of sea defence structures such as embankments as part of managed realignment (French 2008; Pethick 1993; Sterr 2008; van Slobbe et al. 2013).

Planned retreat/realignment is the most controversial adaptation measure with several advantages and disadvantages debated in the literature (see Table 6). While it offers several environmental benefits (Harman et al. 2013; Pethick 1993), the gradual relocation to higherground can take several decades (Barron et al. 2012). The benefits are greatest if the planning and implementation of retreat takes place early in the adaptation process; however, as this is 
not usually possible adaptation may not be as successful as it should be, especially in response to greater increases in sea levels (Nicholls 2011). In general, managed retreat behind the coast involves encouraging wetland survival by removing flood defence structures (Pethick 2002) and improving catchment management that allows coastal erosion to continue and enable wetlands to grow in place (Nicholls et al. 1999). The main barriers to the implementation of planned retreat include socio-political implications (e.g. community resistance), the lack of suitable land, and legal and land tenure issues. In their study of South East Queensland, Australia, Abel et al. (2011) identified the main reasons for the absence of managed retreat from the policy agenda as the promotion of population growth by state governments, a lack of urgency on the need to provide space for protective natural ecosystems, liability issues favouring development, incremental planning that ignores the cumulative impacts on socioecological thresholds, and political pressures from the residents to build defence structures. The socio-political cost of retreat is high (Bray et al. 1997; Catenacci and Giuponni 2013; Harman et al. 2013). Alexander et al. (2012) underscored the negative political implications of managed retreat for coastal urban planning departments in terms of withholding tenable land from the market, especially considering the long timeframes of SLR. Retreat is the least publicly acceptable option, despite being more likely to support sustainability (Lonsdale et al. 2008). Sahin et al. (2013) found retreat to be the preferable option for politicians and to some extent by experts, but the least preferred for the community. This may be due to attachment of the communities to their existing lifestyles. In island states for instance, people are attached to their homes (mostly on high risk land) as the cultural heritage from their ancestors (Primo 1997). Cultural perception of land loss and community preference for in situ adaptation options means that any planned retreat strategy at state level first needs to consider the socioeconomic impacts of population dispersal and mixing (Harman et al. 2013; Lonsdale et al. 2008; Primo 1997; Small et al. 2016). Increased coastal 
land loss under a retreat option has unacceptable political and financial consequences. Wealthy property owners exert pressure to build along the coasts and politicians feel compelled to respond to SLR and coastal flooding. This translates into significant financial burden on the community for the construction of many barriers and coastal works (Devoy 1992; Harman et al. 2013). In the cases of Byron Bay and Port Macquarie in Australia, despite planned retreat policies that clearly prohibit hard structural protection measures (such as seawalls), community concerns and angst forced local governments to continue to build protective structures on some sections of the beach (Harman et al. 2013). Relocation is socially complex and requires the use of incentives for the community to move out, unless the urgency of the threat is too great (Lonsdale et al. 2008).

[Table 6 near here]

Existing settlement patterns, such as shanty towns built in high-risk areas in many developing countries, are significant barriers to good planning in the face of SLR (Nicholls 1995). The lack of suitable land for relocation can form a physical limitation (Harman et al. 2013; Leatherman and Beller-Simms 1997; Munji et al. 2013; Primo 1997; Scott et al. 2012). This in return can lead to the clearing of more mangroves and trigger more environmental problems for the communities (Munji et al. 2013). Planned retreat is also very likely to result in major legal disputes and have considerable impact on property values (Scott et al. 2012). Land use controls that prohibit or limit new development in high risk areas can be challenged in the courts as the 'taking' of private land and create land tenure and liability issues for local governments (Platt 1985; Primo 1997).

Strategic land use planning including overlay zones and tiered zones with strict regulations in vulnerable areas (including increased buffers, setback, density, etc.) are crucial 
for implementing a retreat strategy over a specified timeline (Susskind 2010). Setbacks (including natural buffers) are generally considered as a low-cost alternative to hard protection and also preserve natural shoreline dynamics (Harman et al. 2013). Adaptive management strategies for realignment include planning policy (statutory and non-statutory mechanisms for protection of saltmarshes and mangroves), buffer zones based on vegetation, ensuring that development positively contributes to the rehabilitation and improvement of adjoining estuarine areas and mangroves, prohibiting the filling of land adjacent to wetlands, and initiating revegetation programs targeted at saltmarsh planting (Harty 2004). These require changes to coastal governance (Abel et al. 2011). The periodic review of setbacks is crucial to ensure that necessary buffer zones provide protection (Harman et al. 2013). The consideration of safety margins (setbacks) are complementary to other adaptation measures that are not flexible or reversible (Hallegatte 2009). Relaxing the existing zoning regulations to allow for retreat can be problematic in many cities for political, environmental, and economic reasons; however, alternative strategies such as increasing densities in areas outside hazard zones can be easier to implement and more effective (Frazier et al. 2010).

A retreat strategy can also include phasing out existing protection measures such as beach nourishment programs and not instituting them in new areas (Frazier et al. 2010). Prohibiting protection measures such as seawalls are easy to implement because they do not interfere with the use of the property over several decades, nor does it deprive people of their rights to develop (Titus 1990). However, with SLR the local governments might not be able to resist community pressures to repeal these limitations to protect properties (Titus 1990).

Conditional development strategies include allowing temporary developments in high risk areas on the condition that they will be abandoned if necessary and bounding development approvals with a limited lifespan (Harman et al. 2013). An example is modifying the conventions of property ownership such as leases to expire at a remote date 
when the 'condition' such as a high tide or excessive flooding occurs, with the property reverting to a private conservancy or the government afterwards (Titus 1990). In practice, enforcing contracts is a much easier option for local governments and the courts compared to enforcing regulations (Titus 1990).

Several market-based tools can facilitate retreat including tools relevant to land acquisitions in high risk areas as well as the disclosure of risk information. Coupling aggressive land acquisition with incentives can steer development away from hazard zones (Frazier et al. 2010). Incentives include facilitating land swaps that trade ownership of developed areas near the coast via transferrable development rights for land owned by the government located outside risk zones (Frazier et al. 2010; Susskind 2010; Taylor et al. 2013) and providing legal foundations for government buy-outs such as establishing and funding a buy-out program (de Almeida and Mostafavi 2016; Susskind 2010). While public land acquisition is very expensive (Platt 1985) and restricted by the availability of funding, it can help redistribute the cost of maintaining the public coastal land access and amenity (Taylor et al. 2013; Titus 1986). Government land purchases are also crucial to allow ecosystem migration (Titus 1990). Rolling easement is an important policy tool in this context (Alexander et al. 2012; Harty 2004; McLaughlin 2011; Walsh et al. 2004; Wolf 2013). The integration of dynamic public easements to allow the public to use the dry sand portions of the beach and prohibit any structures on these areas will allow nature to take its course (McLaughlin 2011). The rolling easement boundaries can move with vegetation line and expand public interest in the coastal zone (McLaughlin 2011; Wolf 2013). However, existing common law rules that may not adequately respond to the impacts of SLR can form an important barrier to the effective use of this policy tool. For example, court rulings in Texas, USA allowed private property owners to exclude the public from using sections of the state's 
beaches and prevented the government from removing defence structures, which can cause liability issues for local government (McLaughlin 2011).

A less costly approach is modifying existing institutions to make it possible for markets and governments to anticipate problems as new information regarding SLR becomes available (Titus 1986). For example, siting a marina on marshland prohibited for development can be allowed if some parts of it can be planned to be lost to SLR (Titus 1986). Mandatory disclosure statement about the vulnerability of a property to SLR and coastal flooding as part of all real estate transactions can also facilitate planned retreat (Godschalk et al. 2000; Susskind 2010). Another tool in this context is abandoning development to private market force, with the developers accepting the full risk and allowing the markets to decide whether a property is worth developing despite the risks (Bray et al. 1997; Titus 1990).

To be effective managed retreat needs to be implemented on a larger scale, as the retreat of an isolated section of the coast can increase erosion in the remainder of the system, especially if constrained by coastal defence structures (French 2008; Pethick 1993). Moreover, it needs to be complemented by a community engagement process that encourages all groups to be involved (Abel et al. 2011; Alexander et al. 2012). Government leadership and support are crucial for the success of retreat strategies. In most cases, local governments have the statutory responsibility for local planning and development assessments, but they do not have the capability to manage legal, political, and financial risks associated with planning decisions such as retreat (Harman et al. 2013). Joint action by local and state governments is required for a successful retreat strategy (Taylor et al. 2013). Cost-sharing partnerships between local and regional governments and infrastructure and emergency management groups are necessary to build high capacity and well-connected infrastructure outside the risk zones (Frazier et al. 2010). 


\subsubsection{Migration}

Migration in response to environmental disturbances is not new. Climate change contributes to the environmental conditions that induces coastal out-migration (Abdullah et al 2019). This may be permanent dislocation due to increased coastal erosion or soil salinity as in the cases of Nigeria (Fasona and Omojola 2009) and Bangladesh (Chen and Mueller 2018). However, these occurrences are different than the concept of 'adaptive migration' which includes a broad range of actions including proactively moving out of an area of risk exposure (Martin et al. 2017). There is debate over the effectiveness of migration as an adaptation option (Siddiqui and Hossain 2019) and policy debates to date have focused on the impacts of climate change on migration flows rather than capitalizing on opportunities migration offers as a form of adaptation (Black et al. 2011). In order to help build adaptive capacity migration needs to be facilitated appropriately. This requires policy realignment to include economic and adaptive roles of migration in policy framing (Martin et al. 2017).

The permanent abandonment of low-lying high risk areas along the coast through migration can be an important adaptation measure, particularly in the context of low-lying island states (Fabiyi and Yesuf 2016; Jamero et al. 2017; Lewis 1990; Munji et al. 2013). Migration is a very complicated task as most communities prefer not to leave and are concerned about losing their social capital and cultural values (Donner and Webber 2014; Douglas et al. 2012; Marengo et al. 2017). Jamero et al. (2017) suggest that the attachment of a community to a place (closely linked to sense of pride and belonging to a community) is the most powerful contributor to a final decision regarding migration. Lewis (1990) considers migration as an insensitive imposition on populations. The cultural background of communities (for instance the native versus new settlers in trans-boundary migrations) can influence people’s perceptions of hazards and their adaptation to a great degree (Munji et al. 2013). The availability of financial resources can play a big role in both constraining and 
enabling migration. The migration process can be delayed by difficulties in obtaining low priced housing in new areas and lead to an increased vulnerability of the community (Douglas et al. 2012; Jamero et al. 2017). Economic reasons, such as availability of jobs, can also directly impact the willingness of a community to migrate (Donner and Webber 2014) as evidenced in the reluctance of island communities to relocate permanently because of concerns about their livelihoods that depend on fishing and similar activities (Jamero et al. 2017). A migration policy needs political acceptance, appropriate planning, sufficient funding, and services for counselling, health, employment, etc. to be successful (Lewis 1990).

\subsubsection{Temporary retreat and relocation}

Many governments respond to community opposition to planned retreat and migration by redesigning their relocation programs, allowing temporary evacuation options, especially for island and delta communities (Jamero et al. 2017; Munji 2013; Musa et al. 2016; Primo 1997). Temporary relocation allows communities to retain temporary houses on the low-lying areas (i.e. islands) for their livelihood, while using permanent houses on the relocated areas during natural hazards. In many cases, people own two parcels of land, one on densely populated coastal fringe and another inland where they practice traditional agro-forestry (Primo 1997). One important condition of such an arrangement is strict compliance of residents with evacuation procedures (Jamero et al. 2017). Another option involves use of makeshift houses suspended above the ground on mangrove poles that can be easily dismantled and moved to higher land in the event of coastal flooding (Munji et al. 2013). However, the broader implications of temporary relocation in terms of its impacts on the communities, or its planning and legal challenges, have been under-researched.

\subsection{Integrated adaptation measures}

There is no single best type of adaptation strategy that can make a given community resilient 
to SLR and coastal flooding in isolation. In most cases a combination of different strategies (mostly focusing on protection, accommodation, and retreat) would be more appropriate. For instance, Nicholls (2011) suggests an appropriate mixture of protection, accommodation, and retreat to identify win-win situations for adaptation to SLR in the long-term while solving current problems; however, the implications of an integrated approach is largely unexplored (Table 5). Barron et al. (2012) and Lonsdale et al. (2008) discuss a combination of protection and retreat strategies in terms of reinforcing existing protection in some areas and the relocation from unprotected areas. Yet, despite evaluations of the benefits of relocation or hard protection separately, the cumulative benefits of integrated responses are neglected.

Most articles in the review suggest structural measures need to be supported by nonstructural measures (e.g. Munaretto et al. 2012). For example, building safe shelters and raising community awareness as part of adaptation in situ can help avoid relocation and all the social and political stigma attached to it (Saroar and Routray 2010). However, as Birkmann et al. (2010) suggest, more research is required in this area due to the lack of clarity on how to combine structural and non-structural measures effectively.

\section{Discussion}

A comprehensive overview of various types of adaptation strategies and measures to respond to SLR and coastal flooding point to two critical conclusions with significant policy and research implications derived from the existing literature:

(1) There is no silver bullet for adaptation to coastal flooding and SLR. Adaptation to the coastal impacts of climate change needs to be based on, and tailored to, a comprehensive assessment of local characteristics (e.g. climate, geography, etc.) in each city/case and a combination of different structural and non-structural measures will need to be implemented. 
(2) While there is some information on the advantages and disadvantages of particular strategies and measures individually, there is a major gap in our knowledge of comparative costs and benefits of alternative adaptation strategies and measures in both the short and long-term contexts, as well as the synergies of using these measures concurrently.

Existing patterns of development in many low-lying areas have been established without any consideration of future climate change. This means that many cities rely heavily on structural and ecosystem-based measures in order to cope with the impacts of coastal flooding and SLR. However, research indicates that there are considerable disadvantages associated with hard measures, such as the high cost of construction/maintenance of the structures, and the possible negative impacts on the environment. While there are several cases of community objection to the construction of hard structures in the literature, a more common issue is their propensity to increase exposure and vulnerability by creating a false sense of security. Hard structural measures that do not require significant changes to lifestyle, such as raising buildings and infrastructure or flood proofing, are more accepted by communities and politicians, as communities usually prefer not to move (Harwitasari and Van Ast 2011). These measures can be effective if the climate change impacts (e.g. rising sea levels) are taken into consideration in their design and implementation. However, despite the cost involved, they may not be effective in the long-term as the sea levels will continue to rise (IPCC 2018) and coastal flooding will become a part of everyday life. This means that in the long-term hard structural measures will eventually fail and communities will ultimately have to relocate to higher ground. Unlike hard protection measures like seawalls, the raising of buildings and infrastructure needs much more institutional support/coordination as well as changes to existing policies and planning schemes. This is an important concern especially for 
more transformative accommodation strategies (e.g. floating houses) which mean a drastic change in the way of life of citizens.

It is difficult to conclude whether ecosystem-based structural protection is overall more cost-effective or better for the environment than hard protection in every case (or even in most cases). Ecosystem-based approaches are effective, efficient, and less harmful to the environment depending on the context and only if applied on a small scale and for a shorter period of time. However, at larger scales these approaches can also be expensive due to the need for continuous monitoring. At the end of the day there is no free lunch. Climate change is a complex and wicked problem (Howes and Dedekorkut-Howes 2012, 2016) with serious impacts and there are no easy or cheap solutions. A well-coordinated, whole of-government, cross-sectoral adaptation response requires substantial funding, political support, and leadership (Dedekorkut-Howes and Howes 2014). Moreover, implementation of ecosystembased measures (particularly with regards to their economic and social benefits) are hard to assess and are yet to be articulated in policy and planning. Given the importance of hybrid adaptation measures globally (UNEP n.d.), it is critical to identify and assess the advantages and disadvantages of these measures and their implications.

Non-structural adaptation strategies are more popular in comparison to hard and ecosystem-based structural measures as they are easier to change with much lower sunk costs (Hallegatte 2009). Aside from the general consensus in the literature that non-structural measures are 'good' and can be cost-effective, there has been very limited analysis of the actual cost and benefits of these measures, partly due to the complexity of analysing the multifaceted systems as well as the difficulty in measuring related intangible benefits. Considering the negative community response to both hard and ecosystem-based protection measures, and the complexity of the different social, economic, and legal aspects associated with structural measures, it is clear that non-structural strategies need to be holistic and 
include the community and other stakeholders (i.e. the social, political, financial, and legal actors) at different levels for a coordinated approach. Closer engagement with the community is particularly important as non-structural strategies would impact on people’s lifestyles.

The most controversial adaptation measure in the literature is the retreat of existing settlements and infrastructure. Most adaptation is incremental, unplanned and in situ whereas the best long-term solution may be transformational ex situ planned adaptation. As Torabi et al. (2018) illustrate, the implications of retreat are severe for large urban centres affecting significant numbers of people. When there is a sizeable tax base the defend strategy becomes viable. Despite various advantages, the implementation of retreat is faced with considerable social, economic, and institutional barriers. Retreat is a particularly sensitive adaptation approach that can negatively impact smaller communities with tighter social bonds. Despite being the least preferred option for the public, retreat will become inevitable for some cities such as Venice, Italy or the Gold Coast, Australia which will eventually need to be abandoned because they cannot be defended indefinitely due to sheer size and geography. For example, Cooper and Lemckert (2012) find that the Gold Coast may survive SLR of $1 \mathrm{~m}$ with costly pre-planned adaptation, but survival seems unlikely in case of $2 \mathrm{~m}$ of sea-level rise or greater. One of the most critical questions that needs to be answered to make sound decisions for effective adaptation then is: Until what point is it still economically viable to defend in cases where retreat is unavoidable in the long-term?

Furthermore, defence is an economically feasible option only in wealthier nations. Developing countries such as Bangladesh that have very high levels of vulnerability do not have the resources to defend and will have no choice but to retreat. Yet, there are many planning-related and legal challenges associated with retreat that need to be considered.

Further evaluation of the relative benefits and costs associated with each of the measures discussed above is especially important for a better understanding of the benefits 
that a combination of various structural and non-structural measures can provide. With the rising sea levels and increased frequency and intensity of coastal flooding, reliance on a single measure or strategy for adaptation will not be sufficient and integrated and more complex strategies will become necessary. These strategies will need to be tailored to the local context which will be geographically and politically different (Torabi et al. 2017).

\section{Conclusions}

This article reviewed the literature on SLR and coastal flooding, identified strategies and measures for adaptation, and examined their advantages/disadvantages and barriers/enablers of their implementation. Our research showed that while the traditional protect, accommodate, and retreat strategies are still highly prevalent, there is considerable ambiguity (and overlap) in what each of these strategies entail. There is a greater emphasis in the literature on hard structural measures for protection against, and accommodation of, the impacts of SLR and coastal flooding compared to ecosystem-based measures. Non-structural measures related to raising awareness and behavioural change are also acknowledged; however, more research is needed to understand their implications. Although retreat from low-lying areas is technically the best option, its implementation in practice is very complex and fraught with difficulties such as opposition from both the local and host communities, a very expensive price tag at larger scales, and constraints in the existing institutional context that require new policy and legal frameworks. Moreover, retreat can be significantly constrained by existing natural resources due to the scarcity of land. Although tools such as land use planning to phase out development in high risk areas, conditional development rights, etc. can help, more research is required into how these tools can be more effectively used for planned retreat.

An important issue with regards to the reliance on (particularly hard) structural measures in responding to the impacts of climate change in the long-term is the uncertainty around how much (and until when) these measures are going to be effective in protecting the 
population. With rising seas, cities will need to build higher and stronger seawalls. Yet, the long-term socioeconomic implications of this in terms of its impact on the local tourism and economy as well as the lifestyle of the local communities is unknown. The accommodation of the impacts of SLR and coastal flooding by building higher buildings and raising the key infrastructure of cities can similarly be effective up to a certain point but even small changes will require considerable changes to existing regulation and policies.

More transformative approaches are required for planned adaptation of cities and communities to SLR and coastal flooding in the long-term. This can include integration of uncertainty within strategic planning by careful consideration of existing barriers and innovative ways to approach the problems (Malekpour et al. 2017). The concept of floating communities has recently been taken up across the world as a promising innovative solution to SLR and coastal flooding. Yet, the economic feasibility of such projects and their implications for local communities, their lifestyle, sense of place, etc. are unknown. There is certainly a need for more integrated and comprehensive adaptation approaches to reap the full benefits of the existing adaptation practices. Retreat from the ocean in some parts of a city (based on sound climate risk assessment), while fortifying existing defence in other parts and accommodating the impacts can all be effective strategies. However, more research is required in order to capture the trade-offs and synergies between these strategies and their cumulative benefits.

\section{Acknowledgements}

We would like to thank the anonymous reviewers for their constructive feedback that strengthened our paper. 


\section{References}

Articles included in the Systematic Quantitative Literature Review are noted with an asterisk.

Abdullah, A.Y.M., A. Masrur, M.S.G. Adnan, M.A.A. Baky, Q.K. Hassan, A. Dewan. 2019. Spatiotemporal patterns of land use/land cover change in the heterogeneous coastal region of Bangladesh between 1990 and 2017. Remote Sensing, 11, 790.

*Abel, N., R. Gorddard, B. Harman, A. Leitch, J. Langridge, A. Ryan, and S. Heyenga. 2011. Sea level rise, coastal development and planned retreat: Analytical framework, governance principles and an Australian case study. Environmental Science \& Policy, 14 (3): 279-288.

*Al-Jeneid, S., M. Bahnassy, S. Nasr, and M. El Raey. 2008. Vulnerability assessment and adaptation to the impacts of sea level rise on the Kingdom of Bahrain. Mitigation and Adaptation Strategies for Global Change, 13 (1): 87-104.

*Alexander, K. S., A. Ryan, and T. G. Measham. 2012. Managed retreat of coastal communities: Understanding responses to projected sea level rise. Journal of Environmental Planning and Management, 55 (4): 409-433.

*Alverson, K. 2012. Vulnerability, impacts, and adaptation to sea level rise taking an ecosystem-based approach. Oceanography, 25 (3): 231-235.

*Ayyub, B. M., and M. Kearney. 2011. Towards the development of regional risk profiles and adaptation measures for sea level rise. Journal of Risk Analysis and Crisis Response, 1 (1): 75 89.

*Babu, D. S. S., S. Sivalingam, and T. Machado. 2012. Need for adaptation strategy against global sea level rise: An example from Saudi coast of Arabian Gulf. Mitigation and Adaptation Strategies for Global Change, 17 (7): 821-836.

*Baric, A., B. Grbec, and D. Bogner. 2008. Potential implications of sea-level rise for Croatia. Journal of Coastal Research, 24 (2): 299-305.

*Barron, S., G. Canete, J. Carmichael, D. Flanders, E. Pond, S. Sheppard, and K. Tatebe. 2012. A climate change adaptation planning process for low-lying, communities vulnerable to sea level rise. Sustainability, 4 (9): 2176-2208.

*Berz, G. 2005. Windstorm and storm surges in Europe: Loss trends and possible counter-actions from the viewpoint of an international reinsurer. Philosophical Transactions of the Royal Society A: Mathematical, Physical and Engineering Sciences, 363 (1831): 1431-1440.

*Birkmann, J., M. Garschagen, F. Kraas, and N. Quang. 2010. Adaptive urban governance: New challenges for the second generation of urban adaptation strategies to climate change. Sustainability Science, 5 (2): 185-206.

Black, R., S.R. Bennett, S.M. Thomas, and J.R. Beddington. 2011. Climate change: Migration as adaptation. Nature, 478(7370): 447-449.

*Boori, M. S., and V. E. Amaro. 2011. A remote sensing and GIS based approach for climate change and adaptation due to sea-level rise and hazards in Apodi-Mossoro estuary, Northeast Brazil. International Journal of Plant, Animal and Environmental Sciences, 1 (1): 14-25.

*Boori, M. S., V. E. Amaro, and A. Targino. 2012. Coastal risk assessment and adaptation of the impact of sea-level rise, climate change and hazards: A RS and GIS based approach in ApodiMossoro estuary, Northeast Brazil. International Journal of Geomatics and Geosciences, 2 (3): 815-832.

Boulton, C., A. Dedekorkut-Howes, and J. A. Byrne. 2018. Factors shaping urban greenspace provision: A systematic review of the literature. Landscape and Urban Planning, 178: 82-101.

*Brammer, H. 2014. Bangladesh’s dynamic coastal regions and sea-level rise. Climate Risk Management, 1: 51-62.

*Bray, M., J. Hooke, and D. Carter. 1997. Planning for sea-level rise on the south coast of England: Advising the decision-makers. Transactions of the Institute of British Geographers, 22 (1): 13-30.

*Cai, F., X. Su, J. Liu, B. Li, and G. Lei. 2009. Coastal erosion in China under the condition of global climate change and measures for its prevention. Progress in Natural Science, 19 (4): 415-426. 
*Camill, P., M. Hearn, K. Bahm, and E. Johnson. 2012. Using a boundary organization approach to develop a sea level rise and storm surge impact analysis framework for coastal communities in Maine. Journal of Environmental Studies and Sciences, 2 (2): 111-130.

Carley, J.T., T. D. Shand, I. R. Coghlan, M. J. Blacka, R. J. Cox, A. Littman, B. Fitzgibbon, G. McLean, and P. Watson. 2010. Beach Scraping as a Coastal Management Option. The 19th NSW Coastal Conference, Batemans Bay, NSW, Australia.

*Catenacci, M., and C. Giupponi. 2013. Integrated assessment of sea-level rise adaptation strategies using a Bayesian decision network approach. Environmental Modelling and Software, 44: 87100.

Chaffin, B.C. and M. Scown. 2018. Social-ecological resilience and geomorphic systems. Geomorphology, 305: 221-230.

*Challender, J. 2016. Storm surge impact to subterranean areas by Hurricane Sandy, and lessons for Japan's storm surge countermeasures. Journal of Disaster Research, 11 (2): 274-284.

Chen, J. and V. Mueller. 2018. Coastal climate change, soil salinity and human migration in Bangladesh. Nature Climate Change, 8(11): 981-987.

Chen, W., G. Zhai, C. Ren, Y. Shi, J. Zhang. 2018. Urban resources selection and allocation for emergency shelters: In a multi-hazard environment. International Journal of Environmental Research and Public Health, 15: 1261.

*Choate III, J. F. 2011. Sea level rise planning for Florida's nuclear energy infrastructure: A wait and “sea” approach. Sea Grant Law and Policy Journal, 4 (1): 28-60.

*Cisneros Linares, P. 2013. Sea level rise impacts in coastal zones: Soft measures to cope with it. Dalhousie Journal of Interdisciplinary Management, 8, doi:10.5931/djim.v8i2.282.

*Cooke, B. C., A. R. Jones, I. D. Goodwin, and M. J. Bishop. 2012. Nourishment practices on Australian sandy beaches: A review. Journal of Environmental Management, 113, 319-27.

*Cooper, J. A. G., and C. Lemckert. 2012. Extreme sea-level rise and adaptation options for coastal resort cities: A qualitative assessment from the Gold Coast, Australia. Ocean \& Coastal Management, 64, 1-14.

*Dawson, R. J., T. Ball, J. Werritty, A. Werritty, J. W. Hall, and N. Roche. 2011. Assessing the effectiveness of non-structural flood management measures in the Thames Estuary under conditions of socio-economic and environmental change. Global Environmental Change, 21 (2), 628-46.

*Day Jr, J. W., and P. H. Templet. 1989. Consequences of sea level rise: Implications from the Mississippi Delta. Coastal Management, 17 (3), 241-57.

*de Almeida, B. A., and A. Mostafavi. 2016. Resilience of infrastructure systems to sea-level rise in coastal areas: Impacts, adaptation measures, and implementation challenges. Sustainability, 8 (11), 1115.

*de la Vega-Leinert, A. C. and R. J. Nicholls. 2008. Potential implications of sea-level rise for Great Britain. Journal of Coastal Research, 342-57.

Dedekorkut-Howes, A. and M. Howes. 2014. Climate adaptation policy and planning in South East Queensland. In Responding to Climate Change: Lessons from a Hotspot, edited by P. Burton, 59-67. Collingwood, VIC: CSIRO Publishing.

*DeLorme, D. E., S. H. Stephens, and S. C. Hagen. 2018. Transdisciplinary sea level rise risk communication and outreach strategies from stakeholder focus groups. Journal of Environmental Studies and Sciences, 8(1): 13-21.

*Devoy, R. J. N. 1992. Questions of coastal protection and the human response to sea-level rise in Ireland and Britain. Irish Geography, 25 (1): 1-22.

*Devoy, R. J. N. 2008. Coastal vulnerability and the implications of sea-level rise for Ireland. Journal of Coastal Research, 24 (2): 325-341.

*Donner, S. D., and S. Webber. 2014. Obstacles to climate change adaptation decisions: A case study of sea-level rise and coastal protection measures in Kiribati. Sustainability Science, 9 (3): 331345.

*Douglas, E. M., P. H. Kirshen, M. Paolisso, C. Watson, J. Wiggin, A. Enrici, and M. Ruth. 2012. Coastal flooding, climate change and environmental justice: Identifying obstacles and incentives for adaptation in two metropolitan Boston Massachusetts communities. Mitigation and Adaptation Strategies for Global Change, 17 (5): 537-562. 
Dronkers, J., and J. Mulder. 1990. Strategies for Adaptation to Sea Level Rise. Report of the Coastal Zone Management Subgroup. Geneva: Intergovernmental Panel on Climate Change.

*Ehler, C. N., B. Cicin-Sain, R. Knecht, R. South, and R. Weither. 1997. Guidelines to assist policy makers and managers of coastal areas in the integration of coastal management programs and national climate-change action plans. Ocean \& Coastal Management, 37 (1): 7-27.

*Eliot, I., C. M. Finlayson, and P. Waterman. 1999. Predicted climate change, sea-level rise and wetland management in the Australian wet-dry tropics. Wetlands Ecology and Management, 7 (1): 63-81.

*Fabiyi, O. O., and J. Oloukoi. 2013. Indigenous knowledge system and local adaptation strategies to flooding in coastal rural communities of Nigeria. Journal of Indigenous Social Development, 2 (1): 1-19.

*Fabiyi, O. O., and G. U. Yesuf. 2013. Dynamics and characterization of coastal flooding in Nigeria: Implication for local community management strategies. Ife Research Publications in Geography, 12 (1\&2): 45-61.

Fasona, M. and A. Omojola. 2009. Land cover change and land degradation in parts of the southwest coast of Nigeria. African Journal of Ecology, 47(S1): 30-38.

*Fasona, M. J. 2003. Coastal flooding risk and community adaptive strategies in the Western Niger Delta. The Nigeria Journal of Environment and Behavior, 1: 56-62.

*Ferreira, Ó., A. João and R. Taborda. 2008. Implications of sea-level rise for continental Portugal. Journal of Coastal Research, 24 (2): 317-324.

*Fincher, R., J. Barnett, and S. Graham. 2015. Temporalities in adaptation to sea-level rise. Annals of the Association of American Geographers, 105 (2): 263-273.

*Frazier, T. G., N. Wood, and B. Yarnal. 2010. Stakeholder perspectives on land-use strategies for adapting to climate-change-enhanced coastal hazards: Sarasota, Florida. Applied Geography, 30 (4): 506-517.

*French, J. R. 2008. Hydrodynamic modelling of estuarine flood defence realignment as an adaptive management response to sea-level rise. Journal of Coastal Research, 24 (2B): 1-12.

*Godschalk, D. R., R. Norton, C. Richardson, and D. Salvesen. 2000. Avoiding coastal hazard areas: Best state mitigation practices. Environmental Geosciences, 7 (1): 13-22.

*Good, J. W. 1994. Shore protection policy and practices in Oregon: An evaluation of implementation success. Coastal Management, 22 (4): 325-352.

*Gurran, N., B. Norman, and E. Hamin. 2013. Climate change adaptation in coastal Australia: An audit of planning practice. Ocean \& Coastal Management, 86: 100-109.

*Hallegatte, S. 2009. Strategies to adapt to an uncertain climate change. Global Environmental Change, 19 (2): 240-247.

*Hansen, H, S. 2010. Modelling the future coastal zone urban development as implied by the IPCC SRES and assessing the impact from sea level rise. Landscape and Urban Planning, 98 (3): 141-149.

*Haque, A., D. Rahman, and H. Rahman. 2016. The importance of community based approach to reduce sea level rise vulnerability and enhance resilience capacity in the coastal areas of Bangladesh: A review. Journal of Sustainability Science and Management, 11 (2): 81-100.

Harik, G., I. Alameddine, R. Maroun, G. Rachid, D. Bruschi, D. Astiaso Garcia, and M. El-Fadel. 2017. Implications of adopting a biodiversity-based vulnerability index versus a shoreline environmental sensitivity index on management and policy planning along coastal areas. Journal of Environmental Management, 187: 187-200.

*Harman, B. P., S. Heyenga, B. M. Taylor, and C. S. Fletcher. 2013. Global lessons for adapting coastal communities to protect against storm surge inundation. Journal of Coastal Research, 31 (4): 790-801.

*Harty, C. 2004. Planning strategies for mangrove and saltmarsh changes in Southeast Australia. Coastal Management, 32 (4): 405-415.

*Harwitasari, D. and J. A. Van Ast. 2011. Climate change adaptation in practice: People's responses to tidal flooding in Semarang, Indonesia. Journal of Flood Risk Management, 4 (3): 216-233.

*Hay, J. E. and N. Mimura. 2005. Sea-level rise: Implications for water resources management. Mitigation and Adaptation Strategies for Global Change, 10 (4): 717-737. 
Hoppe, T., M. M. van den Berg, and F. H. J. M. Coenen. 2014. Reflections on the uptake of climate change policies by local governments: Facing the challenges of mitigation and adaptation. Energy, Sustainability and Society, 4 (8).

Hoque, M.A.A., S. Phinn, C. Roelfsema, and I. Childs. 2018. Assessing tropical cyclone risks using geospatial techniques. Applied Geography, 98: 22-33.

Howes, M., and A. Dedekorkut-Howes. 2012. Climate adaptation and the Australian system of government: The Gold Coast example. In Environmental Policy Failure: The Australian Story, edited by K. Crowley and K.J. Walker, 116-130. Prahran, VIC: Tilde University Press.

Howes, M., and A. Dedekorkut-Howes. 2016. The rise and fall of climate adaptation governance on the Gold Coast, Australia. In Climate Adaptation Governance in Cities and Regions: Theoretical Fundamentals and Practical Evidence, edited by J. Knieling, 237-250. Hamburg: John Wiley \& Sons, Inc.

Howes, M., L. Wortley, R. Potts, A. Dedekorkut-Howes, S. Serrao-Neumann, J. Davidson, T. Smith, and P. Nunn. 2017. Environmental sustainability: A case of policy implementation failure? Sustainability. 9(2): 165.

*Hurlimann, A., J. Barnett, R. Fincher, N. Osbaldiston, C. Mortreux, and S. Graham. 2014. Urban planning and sustainable adaptation to sea-level rise. Landscape and Urban Planning, 126: 84-93.

*Idllalène, S. 2013. Re-thinking coastal adaptation strategy: From SLR to land risks-Can the water policy fill the coastal strategy vacuum? The case of Morocco. Climatic Change, 120 (4): 713725.

*Idllalène, S., and N. Van Cauwenbergh. 2016. Improving legal grounds to reduce vulnerability to coastal flooding in Morocco - A plea for an integrated approach to adaptation and mitigation. Ocean \& Coastal Management, 120: 189-197.

Intergovernmental Panel on Climate Change (IPCC). 2018. Global Warming of $1.5^{\circ} \mathrm{C}$. Special Report. IPCC Cambridge, UK: Cambridge University Press.

Islam, M.A., D. Mitra, A. Dewan, and S.H. Akhter. 2016. Coastal multi-hazard vulnerability assessment along the Ganges deltaic coast of Bangladesh-A geospatial approach. Ocean \& Coastal Management, 127: 1-15.

*Jallow, B. P., M. K. A. Barrow, and S. P. Leatherman. 1996. Vulnerability of the coastal zone of the Gambia to sea level rise and development of response strategies and adaptation options. Climate Research, 6 (2): 165-177.

*Jallow, B. P., S. Toure, M. M. K. Barrow, and A. A. Mathieu. 1999. Coastal zone of the Gambia and the Abidjan region in Côte d'Ivoire: Sea level rise vulnerability, response strategies, and adaptation options. Climate Research, 12 (2/3): 129-136.

*Jamero, M. L., M. Onuki, M. Esteban, X. K. Billones-Sensano, N. Tan, A. Nellas, H. Takagi, N. D. Thao, and V. P. Valenzuela. 2017. Small-island communities in the Philippines prefer local measures to relocation in response to sea-level rise. Nature Climate Change, 7 (8): 581-586.

*Jianjun, J., and H. Francisco. 2013. Sea-level rise adaptation measures in local communities of Zhejiang Province, China. Ocean \& Coastal Management, 71: 187-94.

*Karvetski, C. W., J. H. Lambert, J. M. Keisler, and I. Linkov. 2011. Integration of decision analysis and scenario planning for coastal engineering and climate change. IEEE Transactions on Systems, Man, and Cybernetics-Part A: Systems and Humans, 41 (1): 63-73.

*Khalil, G. M. D. 1992. Cyclones and storm surges in Bangladesh: Some mitigative measures. Natural Hazards, 6 (1): 11-24.

*Kirshen, P., M. Ruth, and W. Anderson. 2008. Interdependencies of urban climate change impacts and adaptation strategies: A case study of Metropolitan Boston USA. Climatic Change, 86 (1): 105-122.

*Kwadijk, J. C. P., M. Haasnoot, J. P. M. Mulder, M. M. C. Hoogvliet, A. B. M. Jeuken, R. A. A. van der Krogt, N. G. C. van Oostrom, et al. 2010. Using adaptation tipping points to prepare for climate change and sea level rise: A case study in the Netherlands. Wiley Interdisciplinary Reviews: Climate Change, 1 (5): 729-740.

*Lacerda, G. B. M., C. Silva, C. A. P. Pimenteira, R. V. Kopp Jr, R. Grumback, L. P. Rosa, and M. A. V. de Freitas. 2014. Guidelines for the strategic management of flood risks in industrial plant 
oil in the Brazilian coast: Adaptive measures to the impacts by relative sea level rise. Mitigation and Adaptation Strategies for Global Change, 19 (7): 1041-1062.

*Lawrence, J., F. Sullivan, A. Lash, G. Ide, C. Carmeron, and L. McGlinchey. 2015. Adapting to changing climate risk by local government in New Zealand: Institutional practice barriers and enablers. Local Environment, 20 (3): 298-320.

*Leatherman, S. P., and N. Beller-Simms. 1997. Sea-level rise and small island states: An overview. Journal of Coastal Research, (24): 1-16.

*Lee, Y. 2014. Coastal planning strategies for adaptation to sea level rise: A case study of Mokpo, Korea. Journal of Building Construction and Planning Research, 2 (01): 74.

*Lewis, J. 1990. The vulnerability of small island states to sea level rise: The need for holistic strategies. Disasters, 14 (3): 241-249.

Liu, Y., Y. Liu, J. Li, W. Lu, X. Wei, C. Sun. 2018. Evolution of landscape ecological risk at the optimal scale: A case study of the open coastal wetlands in Jiangsu, China. International Journal of Environmental Research and Public Health, 15(8): 1691.

*Lonsdale, K. G., T. E. Downing, R. J. Nicholls, D. Parker, A. T. Vafeidis, R. Dawson, and J. Hall. 2008. Plausible responses to the threat of rapid sea-level rise in the Thames Estuary. Climatic Change, 91 (1-2): 145-169.

*Lopez, J. A. 2009. The multiple lines of defense strategy to sustain coastal Louisiana. Journal of Coastal Research, (54): 186-197.

Maanan, M., M. Maanan, H. Rueff, N. Adouk, B. Zourarah and H. Rhinane. 2018. Assess the human and environmental vulnerability for coastal hazard by using a multi-criteria decision analysis. Human and Ecological Risk Assessment: An International Journal, 24(6): 1642-1658.

Malekpour, S., R. R. Brown, F. J. de Haan, and T. H. F. Wong. 2017. Preparing for disruptions: A diagnostic strategic planning intervention for sustainable development. Cities, 63: 58-69.

Mallet, R., J. Hagen-Zanker, R. Slater, and M. Duvendack. 2012. The benefits and challenges of using systematic reviews in international development research. Journal of Development Effectiveness, 4 (3): 445-455.

*Marengo, J. A., L. H. Nunes, C. R. G. Souza, J. Harari, and F. Muller-Karger. 2017. A globally deployable strategy for co-development of adaptation preferences to sea-level rise: The public participation case of Santos, Brazil. Natural Hazards, 88 (1): 39-53.

*Marshall, A., and Allen M. Owens. 2014. Informing rural sea-level rise adaptation strategies through public participation evaluation. International Journal of Climate Change: Impacts \& Responses, 5 (2): 35-47.

Martin, M., Y.H. Kang, M. Billah, T. Siddiqui, R. Black, and D. Kniveton. 2017. Climate-influenced migration in Bangladesh: The need for a policy realignment. Development Policy Review, 35: O357-O379.

Masuya, A., A. Dewan, and R.J. Corner. 2015. Population evacuation: Evaluating spatial distribution of flood shelters and vulnerable residential units in Dhaka with geographic information systems. Natural Hazards, 78(3): 1859-1882.

McGranahan, G., D. Balk, and B. Anderson. 2007. The rising tide: Assessing the risks of climate change and human settlements in low elevation coastal zones. Environment and Urbanization, 19 (1): 17-37.

*McLaughlin, R. J. 2011. Rolling easements as a response to sea level rise in coastal Texas: Current status of the law after Severance v. Patterson. Journal of Land Use \& Environmental Law, 26 (2): 365-394.

Moher, D., A. Liberati, J. Tetzlaff, D.G. Altman, The PRISMA Group. 2009. Preferred reporting items for systematic reviews and meta-analyses: The PRISMA statement. PLoS Medicine 6(7): e1000097.

*Moser, S. C. 2005. Impact assessments and policy responses to sea-level rise in three US states: An exploration of human-dimension uncertainties. Global Environmental Change, 15 (4), 353-69.

Mullick, M.R.A., A.H. Tanim, and S.S. Islam. 2019. Coastal vulnerability analysis of Bangladesh coast using fuzzy logic based geospatial techniques. Ocean \& Coastal Management, 174: 154169. 
*Munaretto, S. and D. Huitema. 2012. Adaptive comanagement in the Venice lagoon? An analysis of current water and environmental management practices and prospects for change. Ecology and Society, 17 (2): 19.

*Munaretto, S., P. Vellinga, and H. Tobi. 2012. Flood protection in Venice under conditions of sealevel rise: An analysis of institutional and technical measures. Coastal Management, 40 (4): 355-380.

*Munji, C. A., M. Y. Bele, A. F. Nkwatoh, M. E. Idinoba, O. A. Somorin, and D. J. Sonwa. 2013. Vulnerability to coastal flooding and response strategies: The case of settlements in Cameroon mangrove forests. Environmental Development, 5 (1): 54-72.

*Musa, Z. N., I. Popescu, and A. Mynett. 2016. Assessing the sustainability of local resilience practices against sea level rise impacts on the lower Niger delta. Ocean \& Coastal Management, 130: 221-228.

*Nicholls, R. J. 1995. Coastal megacities and climate change. GeoJournal, 37 (3): 369-379.

*Nicholls, R. J. 2011. Planning for the impacts of sea level rise. Oceanography, 24 (2): 144-157.

*Nicholls, R. J., and A. Cazenave. 2010. Sea-level rise and its impact on coastal zones. Science, 328 (5985): 1517-1520.

*Nicholls, R. J. and S. P. Leatherman. 1995. The implications of accelerated sea-level rise for developing countries: A discussion. Journal of Coastal Research, SI (14): 303-323.

*Nicholls, R. J., F. M. J. Hoozemans, and M. Marchand. 1999. Increasing flood risk and wetland losses due to global sea-level rise: Regional and global analyses. Global Environmental Change, 9: S69-S87.

Oxford English Dictionary. n.d. Oxford Living Dictionaries. <https://en.oxforddictionaries.com/>

*Paskoff, R. P. 2004. Potential implications of sea-level rise for France. Journal of Coastal Research, 20 (2): 424-434.

*Pethick, J. 1993. Shoreline adjustments and coastal management: Physical and biological processes under accelerated sea-level rise. Geographical Journal, 159 (2): 162-168.

*Pethick, J. 2002. Estuarine and tidal wetland restoration in the United Kingdom: Policy versus practice. Restoration Ecology, 10 (3): 431-437.

Pickering, C. M. and J. Byrne. 2014. The benefits of publishing systematic quantitative literature reviews for $\mathrm{PhD}$ candidates and other early career researchers. Higher Education Research and Development, 33 (3): 534-548.

*Pilarczyk, K. W. and N. S. Nuoi. 2005. Experience and practices on flood control in Vietnam. Water International, 30 (1): 114-122.

*Platt, R. H. 1985. Congress and the coast. Environment: Science and Policy for Sustainable Development, 27 (6): 12-40.

*Primo, L. H. 1997. Sea-level rise vulnerability of Kosrae, Federated States of Micronesia and strategies for adaptation. Journal of Coastal Research, 24: 107-115.

*Rosenzweig, C., W. Solecki, S. A. Hammer, and S. Mehrotra. 2011. Developing coastal adaptation to climate change in the New York City infrastructure-shed: Process, approach, tools, and strategies. Climatic Change, 106 (1): 93-127.

*Sahin, O., S. Mohamed, J. Warnken, and A. Rahman. 2013. Assessment of sea-level rise adaptation options: Multiple-criteria decision-making approach involving stakeholders. Structural Survey, 31 (4): 283-300.

*Sales Jr, R. F. M. 2009. Vulnerability and adaptation of coastal communities to climate variability and sea-level rise: Their implications for integrated coastal management in Cavite City, Philippines. Ocean \& Coastal Management, 52 (7): 395-404.

*Saroar, M., and J. K. Routray. 2010. Adaptation in situ or retreat? A multivariate approach to explore the factors that guide the peoples' preference against the impacts of sea level rise in coastal Bangladesh. Local Environment, 15 (7): 663-686.

*Scott, D., M. C. Simpson, and R. Sim. 2012. The vulnerability of Caribbean coastal tourism to scenarios of climate change related sea level rise. Journal of Sustainable Tourism, 20 (6): 883898.

Siddiqui M.R. and M.A. Hossain. 2019. Climate change and migration in coastal areas in South Asia. In Climate Action. Encyclopedia of the UN Sustainable Development Goals, edited by Leal Filho W., A. Azul, L. Brandli, P. Özuyar amd T. Wall. Cham: Springer. 
*Small, C., T. Blanpied, A. Kauffman, C. O’Neil, N. Proulx, M. Rajacich, H. Simpson, et al. 2016. Assessment of damage and adaptation strategies for structures and infrastructure from storm surge and sea level rise for a coastal community in Rhode Island, United States. Journal of Marine Science and Engineering, 4 (4): 67.

*Solecki, W. 2012. Urban environmental challenges and climate change action in New York City. Environment and Urbanization, 24 (2): 557-573.

*Solecki, W., R. Leichenko, and K. O’Brien. 2011. Climate change adaptation strategies and disaster risk reduction in cities: Connections, contentions, and synergies. Current Opinion in Environmental Sustainability, 3 (3): 135-141.

*Sterr, H. 2008. Assessment of vulnerability and adaptation to sea-level rise for the coastal zone of Germany. Journal of Coastal Research, 24 (2): 380-393.

*Storbjörk, S., and J. Hedrén, 2011. Institutional capacity-building for targeting sea-level rise in the climate adaptation of Swedish coastal zone management: Lessons from Coastby. Ocean \& Coastal Management, 54 (3): 265-273.

*Storch, H., and N. K. Downes. 2011. A scenario-based approach to assess Ho Chi Minh City's urban development strategies against the impact of climate change. Cities, 28 (6): 517-526.

*Susskind, L. 2010. Responding to the risks posed by climate change: Cities have no choice but to adapt. Town Planning Review, 81 (3): 217-235.

Sutton-Grier, A. E., K. Wowk, and H. Bamford. 2015. Future of our coasts: The potential for natural and hybrid infrastructure to enhance the resilience of our coastal communities, economies and ecosystems. Environmental Science \& Policy, 51: 137-148.

*Symes, D., D. Akbar, M. Gillen, and P. Smith. 2009. Land-use mitigation strategies for storm surge risk in South East Queensland. Australian Geographer, 40 (1): 121-136.

*Taylor, B. M., B. P. Harman, and M. Inman. 2013. Scaling-up, scaling-down, and scaling-out: Local planning strategies for sea-level rise in New South Wales, Australia. Geographical Research, 51 (3): 292-303.

*Titus, J. G. 1986. Greenhouse effect, sea level rise, and coastal zone management. Coastal Management, 14 (3): 147-171.

*Titus, J. G. 1990. Strategies for adapting to the greenhouse effect. Journal of the American Planning Association, 56 (3): 311-323.

*Titus, J. G., C. Y. Kuo, M. J. Gibbs, T. B. LaRoche, M. K. Webb, and J. O. Waddell. 1987. Greenhouse effect, sea level rise, and coastal drainage systems. Journal of Water Resources Planning and Management, 113 (2): 216-227.

*Tobey, J., P. Rubinoff, D. Robadue Jr, G. Ricci, R. Volk, J. Furlow, and G. Anderson. 2010. Practicing coastal adaptation to climate change: Lessons from integrated coastal management. Coastal Management, 38 (3): 317-335.

*Tol, R. S. J., R. J. T. Klein, and R. J. Nicholls. 2008. Towards successful adaptation to sea-level rise along Europe's coasts. Journal of Coastal Research, 24 (2): 432-442.

*Tol, R. S. J., M. Bohn, T. E. Dowing, M. L. Guillerminet, E. Hizsnyik, R. Kasperson, K. Lonsdale, et al. 2006. Adaptation to five metres of sea level rise. Journal of Risk Research, 9 (5): 467-482.

Torabi, E., A. Dedekorkut-Howes, and M. Howes. 2018. Adapting or maladapting: Building resilience to climate-related disasters in coastal cities. Cities, 72: 295-309.

Torabi, E., A. Dedekorkut-Howes, and M. Howes. 2017. Not waving, drowning: Comparing local government initiatives on climate change adaptation and disaster risk management. Urban Policy and Research, 35(3): 312-332.

*Trang, N. T. T. 2016. Architectural approaches to a sustainable community with floating housing units adapting to climate change and sea level rise in Vietnam. World Academy of Science, Engineering and Technology, International Journal of Civil, Environmental, Structural, Construction and Architectural Engineering, 10 (2): 168-179.

UN (United Nations). n.d. Atlas of the Oceans, $<$ http://www.oceansatlas.org/servlet/CDSServlet?status=ND0xODc3JjY9ZW4mMzM9KiYz Nz1rb3M >, accessed 1 February 2018.

UN-Habitat (United Nations Human Settlements Programme). 2013. State of the World's Cities 2012/2013. Kenya: United Nations Human Settlements Programme (UN-Habitat) and Routledge. 
UNEP (United Nations Environment Programme). n.d. Coastal Ecosystem-Based Adaptation Options. $<$ http://web.unep.org/coastal-eba/EBA-options>, accessed 26 November 2018.

UNISDR (United Nations International Strategy for Disaster Reduction). 2009. Terminology on Disaster Risk Reduction. Geneva, Switzerland: United Nations Intenrational Strategy for Disaster Reduction.

USACE (US Army Corps of Engineers). 2003. Glossary of Coastal Engineering. USACE.

van den Berg, M., and F. Coenen. 2012. Integrating climate change adaptation into Dutch local policies and the role of contextual factors. Local Environment, 17 (4): 441-460.

*van Slobbe, E., H. J. de Vriend, S. Aarninkhof, K. Lulofs, M. de Vries, and P. Dircke. 2013. Building with nature: In search of resilient storm surge protection strategies. Natural Hazards, 66 (3): 1461-1480.

*van Wesenbeeck, B. K., J. P. M. Mulder, M. Marchand, J. Denise, M. B. de Vries, H. J. de Vriend, and P. M. J. Herman. 2014. Damming deltas: A practice of the past? Towards nature-based flood defenses. Estuarine, Coastal and Shelf Science, 140: 1-6.

*VanKoningsveld, M., J. P. M. Mulder, M. J. F. Stive, L. Van Der Valk, and A. W. Van Der Weck. 2008. Living with sea-level rise and climate change: A case study of the Netherlands. Journal of Coastal Research, 24 (2): 367-379.

*Vellinga, P., and R. J. T. Klein. 1993. Climate change, sea level rise and integrated coastal zone management: An IPCC approach. Ocean \& Coastal Management, 21 (1-3): 245-268.

*Vellinga, P., and S. P. Leatherman. 1989. Sea level rise, consequences and policies. Climatic Change, 15 (1): 175-189.

*Walsh, K. J. E., H. Betts, J. Church, A. B. Pittock, K. L. McInnes, D. R. Jackett, and T. J. McDougall. 2004. Using sea level rise projections for urban planning in Australia. Journal of Coastal Research, 20 (2): 586-598.

*Wang, J., W. Gao, S. Xu, and L. Yu. 2012. Evaluation of the combined risk of sea level rise, land subsidence, and storm surges, and strategies for minimizing damage to coastal areas of Shanghai. Climatic Change, 115: 537-558.

*Wolf, M. A. 2013. Strategies for making sea-level rise adaptation tools “takings-proof”'. Journal of Land Use, 28 (2):, 157-196.

*Wong, P. P. 1992. Impact of a sea level rise on the coasts of Singapore: Preliminary observations. Journal of Southeast Asian Earth Sciences, 7 (1): 65-70.

*Yuliadi, D., Eriyatno, M. Y. J. Purwanto, and W. I. Nurjaya. 2016. Socio economical impact analysis and adaptation strategy for coastal flooding case study on North Jakarta Region. International Journal on Advanced Science, Engineering and Information Technology, 6 (3): 390-393.

*Yusuf, J. E., K. Neill, B. S. John, I. K. Ash, and K. Mahar. 2016. The sea is rising... but not onto the policy agenda: A multiple streams approach to understanding sea level rise policies. Environment and Planning C: Government and Policy, 34 (2): 228-243. 
Table 1. Key strategies and measures in adaptation to sea level rise and coastal flooding

\begin{tabular}{|c|c|c|c|c|c|c|}
\hline \multirow{2}{*}{\multicolumn{3}{|c|}{ Strategy and Measure Type }} & \multirow[t]{2}{*}{ Definition } & \multirow[t]{2}{*}{ Measures (number of articles) } & \multicolumn{2}{|c|}{$\begin{array}{l}\text { Literature Coverage } \\
(\mathrm{n}=119)\end{array}$} \\
\hline & & & & & Measure & Strategy \\
\hline \multirow{6}{*}{ 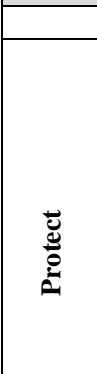 } & \multicolumn{2}{|c|}{ Attack } & Extending towards the water & Land reclamation (1), piers, decks, and ports (1) & (2) $1.7 \%$ & (2) $1.7 \%$ \\
\hline & \multirow{5}{*}{ Structural } & Hard & Manmade structures to block water & $\begin{array}{l}\text { Seawalls (45), dikes (29), groynes (17), levees (17), breakwater (15), flood } \\
\text { barriers and gates (14), embankments (12), coastal dams (8), jetties (7), } \\
\text { sandbags (5), gabion basket (5), piers (1) }\end{array}$ & (64) $53.8 \%$ & \multirow{6}{*}{ (81) $68.0 \%$} \\
\hline & & \multirow{2}{*}{ Soft } & Ecosystem-based barriers for water & $\begin{array}{l}\text { Wetlands (18), mangroves (13), saltmarshes (12), afforestation and } \\
\text { reforestation (10) }\end{array}$ & & \\
\hline & & & Human interventions to enhance capacity of natural barriers & $\begin{array}{l}\text { Beach nourishment (35), dune restoration (19), land reclamation (13), } \\
\text { replenishment (8), scraping (1) }\end{array}$ & (b1) $43.0 \%$ & \\
\hline & & \multirow[b]{2}{*}{ Hybrid } & Combination of hard and soft protection & Dikes/seawalls and ecological barriers (e.g. beach nourishment) (9) & \multirow[b]{2}{*}{ (11) $9.2 \%$} & \\
\hline & & & Soft engineering solutions & $\begin{array}{l}\text { Geosynthetic containers (4), geotextile dune restoration (1), beach drainage } \\
\text { (1), beach dewatering (1), biotechnical structures (1) }\end{array}$ & & \\
\hline & \multicolumn{2}{|c|}{ Non-Structural } & $\begin{array}{l}\text { Measures not involving physical construction but use knowledge, } \\
\text { practice, etc. to reduce risks and impacts }\end{array}$ & Shore protection policy and governance (10), living shoreline strategy (4) & (14) $11.8 \%$ & \\
\hline \multirow{3}{*}{ 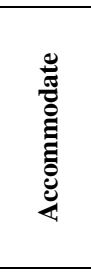 } & \multirow[t]{2}{*}{ Structural } & Hard & Design interventions into the built environment and infrastructure & $\begin{array}{l}\text { Elevating buildings and infrastructure (36), flood proofing (27), upgrading } \\
\text { drainage and stormwater systems (23), construction and enhancement of } \\
\text { capacity of shelters (5), floating communities (4) }\end{array}$ & (58) $48.7 \%$ & \multirow{3}{*}{ (78) $65.5 \%$} \\
\hline & & Soft & Ecosystem-based approaches to cope with impacts & $\begin{array}{l}\text { Land reclamation (6), vegetated buffers (4), beach nourishment (2) } \\
\text { conservation of mangroves (1) }\end{array}$ & (15) $12.6 \%$ & \\
\hline & \multicolumn{2}{|c|}{ Non-Structural } & Measures not involving construction & $\begin{array}{l}\text { Building and planning policy (23), early warning (13), compensation (11), } \\
\text { awareness raising (9), evacuation (4), research (3), hazard mapping and } \\
\text { vulnerability assessment (3), tax rebates (3), grants (1) }\end{array}$ & (53) $44.5 \%$ & \\
\hline \multirow{5}{*}{$\underset{\mathscr{\Xi}}{\mathscr{\Xi}}$} & \multirow{2}{*}{\multicolumn{2}{|c|}{\begin{tabular}{|l|} 
Horizontal planned retreat \\
Miqration
\end{tabular}}} & Lateral relocation of assets and communities & Phased relocation of highly vulnerable structures & (52) $43.7 \%$ & \multirow{5}{*}{ (59) $49.6 \%$} \\
\hline & & & Permanent abandonment of an area & Migration from islands to mainland & (7) $6.0 \%$ & \\
\hline & \multirow{2}{*}{\multicolumn{2}{|c|}{\begin{tabular}{|l|} 
Temporary relocation \\
Engineered retreat
\end{tabular}}} & Short term relocation during natural hazards & Moving to higher land during floods & (4) $3.4 \%$ & \\
\hline & & & Land reclamation and filling & Filling of intertidal habitats & (1) $0.9 \%$ & \\
\hline & \multicolumn{2}{|c|}{ Vertical Retreat } & Elevating structures & Raising electric systems, buildings & (1) $0.9 \%$ & \\
\hline \multirow{5}{*}{ 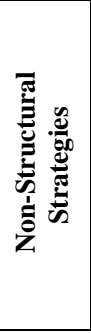 } & \multicolumn{2}{|c|}{ Policy regulation } & Use of regulatory institutional tools to deal with the impacts of coastal & Coastal management, integrated coastal zone management (36) & $\frac{(36) 30.2 \%}{469) 58 \%}$ & \multirow{5}{*}{$\begin{array}{r}(105) \\
89.0 \%\end{array}$} \\
\hline & Communit & city building & $\begin{array}{l}\text { Promoting the capacity of local communities to develop and sustain } \\
\text { their own adaptation }\end{array}$ & $\begin{array}{l}\text { Adaptation planning, anticipatory planning, design, etc. (69) } \\
\text { Learning (23), engagement (21), raising awareness (43), incorporating } \\
\text { indigenous knowledge (4) }\end{array}$ & \begin{tabular}{r|}
$(69) 58 \%$ \\
$(72) 60.5 \%$
\end{tabular} & \\
\hline & \multicolumn{2}{|c|}{ Disaster risk reduction } & $\begin{array}{l}\text { Efforts to reduce the impacts of disasters and vulnerability of } \\
\text { communities }\end{array}$ & $\begin{array}{l}\text { Monitoring and early warning systems (16), forecasting (13), hazard and } \\
\text { vulnerability mapping and assessment (22), research (7), technology (3), } \\
\text { evacuation (4) }\end{array}$ & (50) $42 \%$ & \\
\hline & \multicolumn{2}{|c|}{ Governance } & $\begin{array}{l}\text { Institutional frameworks within which decisions regarding adaptation } \\
\text { are made }\end{array}$ & Adaptive governance (31) & (31) $26.0 \%$ & \\
\hline & \multicolumn{2}{|c|}{ Financial tools } & Use of monetary and fiscal tools in order to shape behaviour & Insurance (22) compensation, tax, and incentives (30) & (43) $36.1 \%$ & \\
\hline \multicolumn{3}{|c|}{ Integrated Strategies } & $\begin{array}{l}\text { Combination of protection, accommodation, and retreat; or structural } \\
\text { and non-structural measures }\end{array}$ & Construction of seawalls and relocation of some areas & (17) $14.3 \%$ & (17) $14.3 \%$ \\
\hline
\end{tabular}


Table 2. Evaluation of hard structural adaptation measures

\begin{tabular}{|c|c|c|c|}
\hline Measures & Advantages & Disadvantages & $\begin{array}{l}\text { Literature } \\
\text { Coverage } \\
(\mathrm{n}=119)\end{array}$ \\
\hline Seawalls & $\begin{array}{l}\text { - Viable for highly developed areas } \\
\text { (Kirshen et al. 2008; Walsh et al. } \\
\text { 2004) } \\
\text { - Prevent socioeconomic damages } \\
\text { associated with relocation (Boori } \\
\text { et al. 2012) }\end{array}$ & $\begin{array}{l}\text { • Cause stress on coastal habitats (Cisneros Linares } \\
\text { 2013; Donner and Webber 2014; Rosenzweig et al. } \\
\text { 2011) } \\
\text { • Expensive (needing resources and maintenance) } \\
\text { (Donner and Webber 2014; Nicholls and Leatherman } \\
\text { 1995) } \\
\text { • Can block views (Barron et al. 2012; Douglas et al. } \\
\text { 2012) } \\
\text { - Not aesthetically pleasing (Scott et al. 2012; Walsh } \\
\text { et al. 2004) }\end{array}$ & (45) $38 \%$ \\
\hline $\begin{array}{l}\text { Elevating buildings and } \\
\text { infrastructure }\end{array}$ & $\begin{array}{l}\text { - Perceived as an effective and } \\
\text { functional option by those who are } \\
\text { willing to pay (Harwitasari and } \\
\text { Van Ast 2011) }\end{array}$ & $\begin{array}{l}\text { • High cost (Birkmann et al. 2010; Frazier et al. 2010) } \\
\text { - May result in unattractive building forms (Douglas et } \\
\text { al. 2012) } \\
\text { - Implementation can take a long time (Douglas et al. } \\
\text { 2012) } \\
\text { - Not feasible in the long-term (Birkmann et al. 2010; } \\
\text { de Almeida and Mostafavi 2016) }\end{array}$ & (36) $30.2 \%$ \\
\hline Dikes & & $\begin{array}{l}\text { - High cost (Nicholls 1995; Vellinga and Leatherman } \\
\text { 1989) } \\
\text { - Can encourage development in high risk areas (Day } \\
\text { Jr and Templet 1989) } \\
\text { - Negative impact on the coastal environment (Day Jr } \\
\text { and Templet 1989; VanKoningsveld et al. 2008; } \\
\text { Vellinga and Leatherman 1989) } \\
\text { - Social acceptability of living behind dikes (Kwadijk } \\
\text { et al. 2010) }\end{array}$ & (29) $24.3 \%$ \\
\hline Flood proofing houses & $\begin{array}{l}\text { - Preferred option by communities } \\
\text { and politicians compared to other } \\
\text { measures (Douglas et al. 2012; } \\
\text { Jamero et al. 2017; Sahin et al. } \\
\text { 2013) } \\
\text { - Cost-effective compared to hard } \\
\text { protection (Titus 1986) } \\
\end{array}$ & $\begin{array}{l}\text { - Some dry techniques can be difficult to implement } \\
\text { (Douglas et al. 2012) } \\
\text { - Need for coordination with protection measures to be } \\
\text { more effective (Douglas et al. 2012) }\end{array}$ & (27) $23 \%$ \\
\hline $\begin{array}{l}\text { Upgrading existing } \\
\text { drainage and stormwater } \\
\text { infrastructure }\end{array}$ & $\begin{array}{l}\text { - Can reduce the cost of maintenance } \\
\text { in the long-term (Titus et al. 1987) } \\
\text { - Reduces the possibility of sewage } \\
\text { backup (de Almeida and Mostafavi } \\
\text { 2016) } \\
\text { - Innovative use of stormater in } \\
\text { artificial aquifer recharge to deal } \\
\text { with saltwater intrusion (de } \\
\text { Almeida and Mostafavi 2016) } \\
\end{array}$ & & (23) $19.3 \%$ \\
\hline Land reclamation & $\begin{array}{l}\text { - Provide buffer areas for protection } \\
\text { that can be used as open space and } \\
\text { roads (Lee 2014) } \\
\text { - Does not prohibit } \\
\text { building/rebuilding on coastal land } \\
\text { (Wolf 2013) }\end{array}$ & $\begin{array}{l}\text { - Requires material and maintenance (Donner and } \\
\text { Webber 2014) } \\
\text { - Large scale reclamation such as creation of artificial } \\
\text { islands is expensive and resource intensive (Donner } \\
\text { and Webber 2014; Vellinga and Leatherman 1989) } \\
\text { • Can reduce the stock of coastal wetlands (Al-Jeneid } \\
\text { et al. 2008) } \\
\text { - Can increase tidal range (Lonsdale et al. 2008) } \\
\text { • Negative environmental impact due to sand dredging } \\
\text { (Walsh et al. 2004) } \\
\text { - Leaves other parts vulnerable and is not effective in } \\
\text { the long-term (Lee 2014) }\end{array}$ & (19) $16 \%$ \\
\hline Groynes & $\begin{array}{l}\text { • Easy to build (Jallow et al. 1996; } \\
\text { 1999) } \\
\text { - Cost-effective (Jallow et al. 1996; } \\
\text { 1999) }\end{array}$ & $\begin{array}{l}\text { - Negative impact on the environment (Jallow et al. } \\
\text { 1996; Rosenzweig et al. 2011) }\end{array}$ & (17) $14.3 \%$ \\
\hline Levees & $\begin{array}{l}\text { - Viable for highly developed areas } \\
\text { (Alexander et al. 2012) }\end{array}$ & $\begin{array}{l}\text { - False sense of safety (Lawrence et al. 2015; van } \\
\text { Wesenbeeck et al. 2014) }\end{array}$ & (17) $14.3 \%$ \\
\hline Breakwater & & $\begin{array}{l}\text { - Expensive (Cisneros Linares 2013; Primo 1997) } \\
\text { - Slowness of implementation (Donner and Webber } \\
\text { 2014) } \\
\text { - Negative impacts on hydrodynamics (Donner and } \\
\text { Webber 2014) }\end{array}$ & (15) $13 \%$ \\
\hline
\end{tabular}




\begin{tabular}{|c|c|c|c|}
\hline Measures & Advantages & Disadvantages & $\begin{array}{l}\text { Literature } \\
\text { Coverage } \\
(n=119)\end{array}$ \\
\hline $\begin{array}{l}\text { Flood and storm surge } \\
\text { barriers }\end{array}$ & $\begin{array}{l}\text { - One-off cost of implementation } \\
\text { (Lonsdale et al. 2008) } \\
\text { - Least disruption to city life } \\
\text { (Lonsdale et al. 2008) } \\
\text { - Transport and electricity } \\
\text { production (Lonsdale et al. 2008). }\end{array}$ & $\begin{array}{l}\text { • Require pumping and drainage (Sterr 2008) } \\
\text { • Expensive (Munaretto et al. 2012; Rosenzweig et al. } \\
\text { 2011) } \\
\text { • Negative environmental impacts (van Slobbe et al. } \\
\text { 2013; van Wesenbeeck et al. 2014) } \\
\text { - Lengthy construction time (Lonsdale et al. 2008) } \\
\text { - Negative social impacts (Lonsdale et al. 2008) } \\
\text { • Require extensive assessment (Rosenzweig et al. } \\
\text { 2011) }\end{array}$ & (14) $12 \%$ \\
\hline Embankments & & $\begin{array}{l}\text { - Negative environmental impact (Pethick 1993, 2002) } \\
\text { - Potential to increase risk of flooding elsewhere } \\
\text { (Pethick 1993, 2002) }\end{array}$ & (12) $10 \%$ \\
\hline Revetments & & • Expensive (Primo 1997) & (11) $9 \%$ \\
\hline Coastal Dams & & $\begin{array}{l}\text { - Expensive (van Wesenbeeck et al. 2014) } \\
\text { - Negative impact on the environment (Hay and } \\
\text { Mimura 2005; Pilarczyk and Nuoi 2005) }\end{array}$ & (8) $7 \%$ \\
\hline Jetties & & - Lead to erosion (Rosenzweig et al. 2011) & (7) $6 \%$ \\
\hline Sandbags & & $\begin{array}{l}\text { - Encourage sand mining and are destructuve in the } \\
\text { long-term (Musa et al. 2016) }\end{array}$ & (5) $4 \%$ \\
\hline $\begin{array}{l}\text { Gabion basket and mesh } \\
\text { rubble mattresses }\end{array}$ & & $\begin{array}{l}\text { - Not suitable for high wave energy environments and } \\
\text { require ongoing maintenance (Donner and Webber } \\
\text { 2014) }\end{array}$ & (5) $4 \%$ \\
\hline $\begin{array}{l}\text { Floating houses and } \\
\text { communities }\end{array}$ & $\begin{array}{l}\text { - Cost sharing (Trag 2016) } \\
\text { • Community building (Trang 2016) }\end{array}$ & & (4) $3.4 \%$ \\
\hline Piers, ports & & $\begin{array}{l}\text { - Leave other parts vulnerable and not effective in the } \\
\text { long-term (Lee 2014) }\end{array}$ & (2) $1.7 \%$ \\
\hline $\begin{array}{l}\text { Others (rubble, artificial } \\
\text { reef, impoundments) }\end{array}$ & & & (6) $5 \%$ \\
\hline
\end{tabular}


Table 3. Evaluation of ecosystem-based structural adaptation measures

\begin{tabular}{|c|c|c|c|}
\hline Measures & Advantages & Disadvantages & $\begin{array}{l}\text { Literature } \\
\text { Coverage } \\
(\mathbf{n}=119)\end{array}$ \\
\hline Beach nourishment & $\begin{array}{l}\text { - Cost efficiency compared to hard } \\
\text { measures (Catenacci and Giupponi } \\
\text { 2013; de Almeida and Mostafavi } \\
\text { 2016; de la Vega-Leinert and } \\
\text { Nicholls 2008; Vellinga and } \\
\text { Leatherman 1989) } \\
\text { - Capacity to enhance natural } \\
\text { processes and biodiversity } \\
\text { (Cisneros Linares 2013; Cooke et } \\
\text { al. 2012; Harman et al. 2013; } \\
\text { Nicholls and Leatherman 1995) } \\
\text { - Conribution to beach amenity, } \\
\text { recreaton, and tourism (Cooke et al. } \\
\text { 2012; de la Vega-Leinert and } \\
\text { Nicholls 2008; Harman et al. 2013) } \\
\text { - Large scale nourishment is more } \\
\text { cost-effective compared to regular } \\
\text { nourishment projects when applied } \\
\text { over the entire coast (van Slobbe et } \\
\text { al. 2013) }\end{array}$ & $\begin{array}{l}\text { - High cost (Cooper and Lemckert 2012; Harman et al. } \\
\text { 2013; Vellinga and Leatherman 1989; Walsh et al. } \\
\text { 2004) } \\
\text { - Requires heavy machinery and technology (Cisneros } \\
\text { Linares 2013) } \\
\text { - Requires constant maintenance, monitoring, and } \\
\text { modelling (Cooke et al. 2012; Cooper and Lemckert } \\
\text { 2012; de Almeida and Mostafavi 2016; Devoy 1992; } \\
\text { Harman et al. 2013; Vellinga and Leatherman 1989) } \\
\text { - Can propel development in high risk areas (Harman } \\
\text { et al. 2013) } \\
\text { - May destroy natural habitats or modify beach } \\
\text { morphology (Cisneros Linares 2013) } \\
\text { - Mega norishment projects can change the alignment } \\
\text { of the coast and create dangerous currents (van } \\
\text { Slobbe et al. 2013) } \\
\text { - Can have negative impact on fresh groundwater } \\
\text { quality stored in dunes (van Slobbe et al. 2013) } \\
\text { - Unknown long effects and temporary/poorly } \\
\text { documented benefits (Cisneros Linares 2013; de } \\
\text { Almeida and Mostafavi 2016; Harman et al. 2013) }\end{array}$ & (37) $30 \%$ \\
\hline $\begin{array}{l}\text { Wetlands, mangroves, } \\
\text { saltmarshes, etc., }\end{array}$ & $\begin{array}{l}\text { - No regrets strategy (Alverson } \\
\text { 2012) } \\
\text { - Enhance the ecological resilience } \\
\text { of the coastal zone (Alverson 2012; } \\
\text { de Almeida and Mostafavi 2016; } \\
\text { Donner and Webber 2014) } \\
\text { - Cost-effective (Donner and Webber } \\
\text { 2014) }\end{array}$ & $\begin{array}{l}\text { - Slow process (Donner and Webber 2014) } \\
\text { - Problems assessing the degree of protection provided } \\
\text { by marshes (Ayyub and Kearney 2011) }\end{array}$ & (26) $22 \%$ \\
\hline Sand/dune restoration & $\begin{array}{l}\text { - Less costly (Cisneros Linares } \\
\text { 2013) } \\
\text { - Enables the recuperation of } \\
\text { morphological features of the } \\
\text { coastal zone (Cisneros Linares } \\
\text { 2013) }\end{array}$ & & (19) $16 \%$ \\
\hline $\begin{array}{l}\text { Reforestation and } \\
\text { afforestation }\end{array}$ & $\begin{array}{l}\text { - Creation of employment, additional } \\
\text { income, and increase in land values } \\
\text { (Cisneros Linares 2013; Khalil } \\
\text { 1992; Musa et al. 2016) } \\
\text { • Enhancing the natural resilience } \\
\text { and biodiversity values (Cisneros } \\
\text { Linares 2013; Musa et al. 2016) }\end{array}$ & & (10) $8.4 \%$ \\
\hline Coral reefs & & & (6) $5 \%$ \\
\hline Beach replenishment & & $\begin{array}{l}\text { - Negative impact on property values due to affecting } \\
\text { water view (Challender 2016) }\end{array}$ & (8) $7 \%$ \\
\hline Natural barrier walls & $\begin{array}{l}\text { - Protect the coastal area including } \\
\text { marshes and biotic communities } \\
\text { (Platt 1985) }\end{array}$ & & (5) $4 \%$ \\
\hline Vegetated buffers & & & (4) $3.4 \%$ \\
\hline Natural drainage & $\begin{array}{l}\text { Provides ecosystem benefits } \\
\text { (wildlife habitats) (Rosenzweig et } \\
\text { al. 2011) }\end{array}$ & & (2) $1.7 \%$ \\
\hline Beach scraping & & $\begin{array}{l}\text { - Not suitable in the long-term due to increased } \\
\text { erosion and narrowing of the beach width (Cooke et } \\
\text { al. 2012) }\end{array}$ & (1) $0.8 \%$ \\
\hline $\begin{array}{l}\text { Other (earth bunds, } \\
\text { berms, coastal } \\
\text { shelterbelt, natural } \\
\text { breakwater, seagrass and } \\
\text { eelgrass planting) }\end{array}$ & & & (5) $4 \%$ \\
\hline
\end{tabular}


Table 4. Evaluation of hybrid structural adaptation measures

\begin{tabular}{|c|c|c|c|}
\hline Measures & Advantages & Disadvantages & $\begin{array}{l}\text { Literature } \\
\text { Coverage } \\
(\mathrm{n}=119)\end{array}$ \\
\hline $\begin{array}{l}\text { Combination of hard and } \\
\text { ecosystem measures }\end{array}$ & $\begin{array}{l}\text { - No regrets strategy (Tobey et al. } \\
\text { 2010) } \\
\text { • Cost saving and efficient (Barron et } \\
\text { al. 2012; Harman et al. 2013) } \\
\text { • Creates high amenity environment } \\
\text { (Harman et al. 2013; Mclaughlin } \\
\text { 2011; Walsh et al. 2004) } \\
\text { - Recreational opportunities (Barron } \\
\text { et al. 2012) }\end{array}$ & $\begin{array}{l}\text { - Need for alterative strategies in the long-term (Jallow } \\
\text { et al. 1996) } \\
\text { - Not suitable for areas with high wave energy and } \\
\text { needs further assessment and monitoring (Harman et } \\
\text { al. 2013) } \\
\text { - Can cause concerns for governments (possibility of } \\
\text { takings and compensation) (McLaughlin 2011) }\end{array}$ & (11) $7.6 \%$ \\
\hline Soft engineering & $\begin{array}{l}\text { - Cost-effective (Donner and Webber } \\
\text { 2014; Lewis 1990; Small et al. } \\
\text { 2016) } \\
\text { - Improved surf conditions (Harman } \\
\text { et al. 2013) }\end{array}$ & & (4) $3.4 \%$ \\
\hline
\end{tabular}


Table 5. Evaluation of non-structural and integrated adaptation measures

\begin{tabular}{|c|c|c|c|}
\hline Measures & Advantages & Disadvantages & $\begin{array}{l}\text { Literature } \\
\text { Coverage } \\
(\mathrm{n}=119)\end{array}$ \\
\hline \multicolumn{4}{|c|}{ Non-structural } \\
\hline $\begin{array}{l}\text { Planning policy and } \\
\text { regulation }\end{array}$ & \begin{tabular}{|l} 
- Cost-effective (DeLorme et al. \\
2018; Jallow et al. 1996)
\end{tabular} & & (78) $65.5 \%$ \\
\hline $\begin{array}{l}\text { Community capacity } \\
\text { building }\end{array}$ & $\begin{array}{l}\text { - Cost-effective (DeLorme et al. } \\
\text { 2018; Jallow et al. 1996) }\end{array}$ & & (72) $60.5 \%$ \\
\hline Disaster risk reduction & • Cost-effective (Khalil 1992) & - No clear effectiveness in the long-term (Khalil 1992) & (52) $43.7 \%$ \\
\hline $\begin{array}{l}\text { Coastal planning and } \\
\text { management }\end{array}$ & & & (39) 33\% \\
\hline $\begin{array}{l}\text { Adaptive management } \\
\text { and governance }\end{array}$ & & & (31) $26 \%$ \\
\hline \multicolumn{4}{|c|}{ Integrated } \\
\hline $\begin{array}{l}\text { Combination of } \\
\text { structural, non-structural } \\
\text { measures, and/or retreat }\end{array}$ & & & (17) $14.3 \%$ \\
\hline
\end{tabular}


Table 6. Evaluation of retreat strategies

\begin{tabular}{|c|c|c|c|}
\hline Measures & Advantages & Disadvantages & $\begin{array}{l}\text { Literature } \\
\text { Coverage } \\
(n=119)\end{array}$ \\
\hline $\begin{array}{l}\text { Planned retreat to higher } \\
\text { land }\end{array}$ & $\begin{array}{l}\text { - Environmental benefits by allowing } \\
\text { natural processes to continue } \\
\text { (Boori and Amaro 2011; Boori et } \\
\text { al. 2012; Bray et al. 1997; Dawson } \\
\text { et al. 201; Harman et al. 2013; } \\
\text { Kirshen et al. 2008; Lonsdale et al. } \\
\text { 2008; Paskoff 2004; Pethick 2002; } \\
\text { 1993; Tol et al. 2006, 2008; van } \\
\text { Slobbe et al. 2013) } \\
\text { - Addresses the problem of scarce } \\
\text { resources as less materials and } \\
\text { resources are required (Devoy } \\
\text { 1992; Lonsdale et al. 2008) } \\
\text { - Less costly compared to structural } \\
\text { measures such as protection (Abel } \\
\text { et al. 2011; Alexander et al. 2012; } \\
\text { Bray et al. 1997; Devoy 1992; } \\
\text { French 2008; Harman et al. 2013) } \\
\text { - No regrets strategy that allows } \\
\text { more flexibility in responding to } \\
\text { future uncertainty (Kirshen et al. } \\
\text { 2008) } \\
\text { - High risk areas can be used for } \\
\text { different purposes such as } \\
\text { parklands and greenways that also } \\
\text { provide food (Rosenzweig et al. } \\
\text { 2011; Symes et al. 2009) or benefit } \\
\text { mitigation (carbon sinks) (Kirshen } \\
\text { et al. 2008) } \\
\text { opan create better housing } \\
\text { ofportunities for vulnerable groups } \\
\text { 2008) } \\
\text { the community (Lonsdale et al. } \\
\text { buildings, water sports centres, } \\
\text { floating houses, etc.) (Lonsdale et } \\
\text { al. 2008) }\end{array}$ & $\begin{array}{l}\text { - Very costly (French 2008; Lonsdale et al. 2008; Tol } \\
\text { et al. 2006), including the high cost of removal and } \\
\text { relocation of existing flood embankments (Pethick } \\
\text { 2002) } \\
\text { - Time consuming and long process (Barron et al. } \\
\text { 2012; Lonsdale et al. 2008; Nicholls 2011) } \\
\text { - Involves highly complex planning processes (Scott et } \\
\text { al. 2012) } \\
\text { - Requires a holistic management strategy (for all parts } \\
\text { of an estuary) (Pethick 1993) } \\
\text { - Not suitable for highly developed urban areas } \\
\text { (Harman et al. 2013) } \\
\text { - Submerged built-up areas and infrastructure can be a } \\
\text { source of contamination and will require extensive } \\
\text { effort, time, and funding by governments to remove } \\
\text { potentially harmful materials including waste and } \\
\text { concrete (Lonsdale et al. 2008) } \\
\text { - Loss of areas of historical, architectural, and cultural } \\
\text { significance (Lonsdale et al. 2008) } \\
\text { - Can contribute to inequality and increase } \\
\text { vulnerability of some groups by relocating them } \\
\text { without compensation and with little choice over } \\
\text { settlement destination where they may be treated } \\
\text { with prejudice (Lonsdale et al. 2008) or due to the } \\
\text { high cost of relocation, increased market uncertainty } \\
\text { and reduced land values, and higher costs for some } \\
\text { individual property owners (Alexander et al. 2012) } \\
\text { - Might lead to tensions within and between host and } \\
\text { relocated communities (due to limited resources) and } \\
\text { the leaders making these decisions will not be very } \\
\text { popular (Lonsdale te al. 2008) } \\
\text { - Can have negative effect on the collective sense of } \\
\text { place of the community (Alexander et al. 2012) } \\
\text { (Scott et al. 2012) }\end{array}$ & (52) $43.7 \%$ \\
\hline Migration & & $\begin{array}{l}\text { - Highly complicated (due to community preferences, } \\
\text { concerns about loss of social capital, etc.) (Donner } \\
\text { and Webber 2014; Douglas et al. 2012; Marengo et } \\
\text { al. 2017) }\end{array}$ & (7) $6 \%$ \\
\hline $\begin{array}{l}\text { Temporary retreat and } \\
\text { relocation }\end{array}$ & & $\begin{array}{l}\text { - Relies on strict compliance of residents with } \\
\text { evacuation procedures (Jamero et al. 2017) }\end{array}$ & (4) $3.4 \%$ \\
\hline
\end{tabular}


Figure 1. Areas of overlap between different types of adaptation strategies and measures in the literature

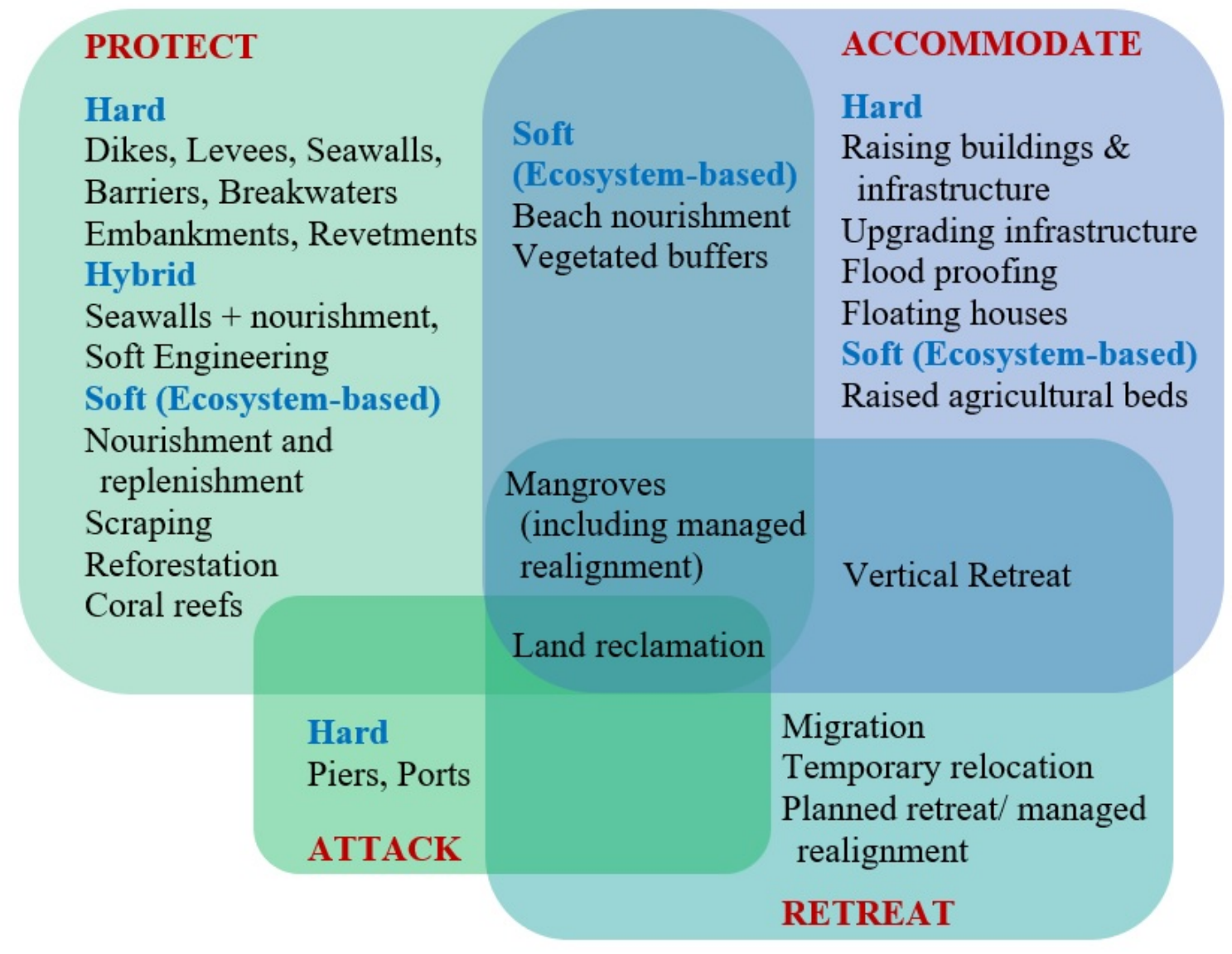


Figure 2. PRISMA flow diagram describing steps for systematic quantitative literature review

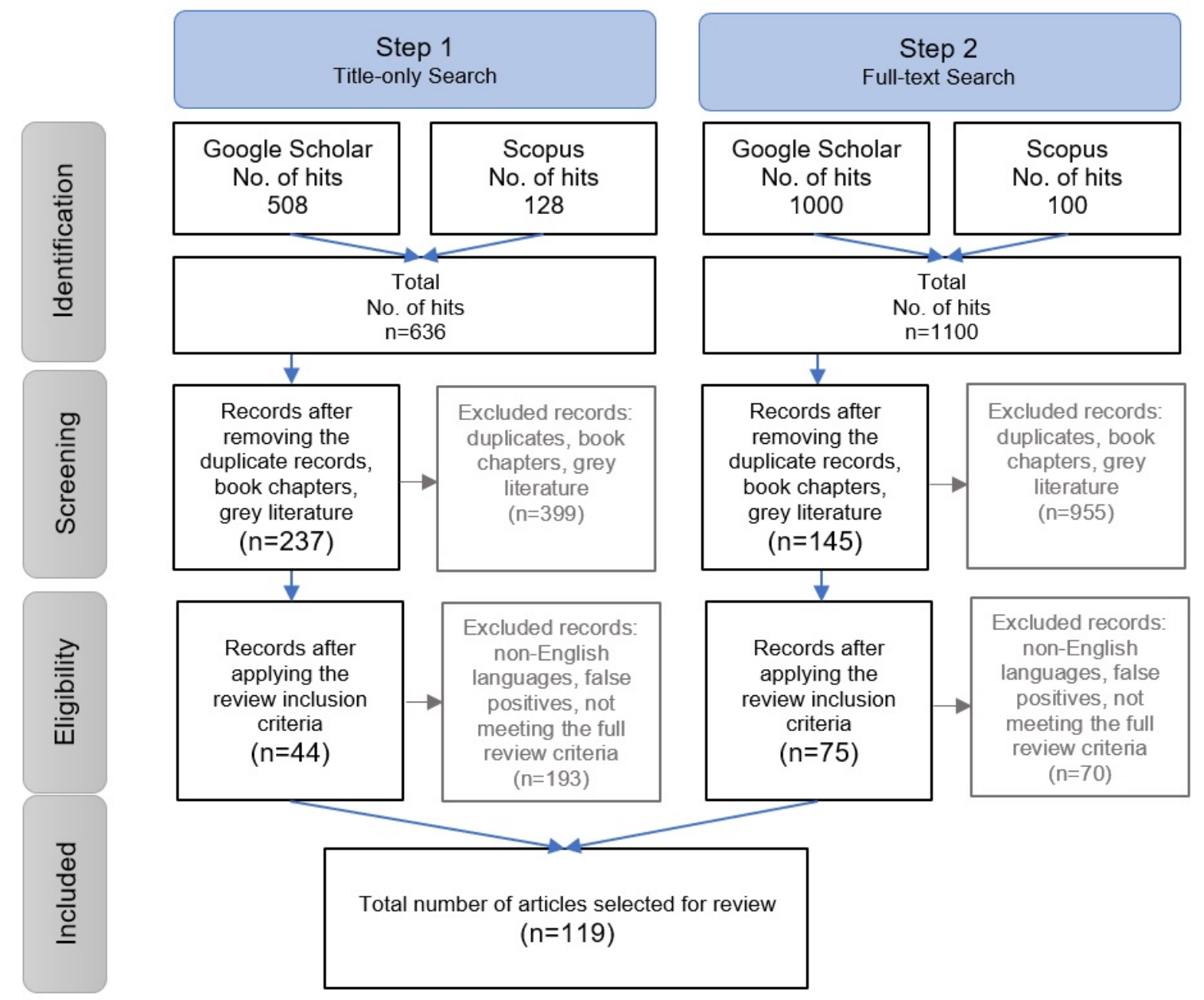

